\title{
An Attorney's Responsibilities Under Federal and State Securities Laws: Private Counselor or Public Servant?
}

\author{
Marshall L. Small*
}

In 1935, Professor Nathan Isaacs of the Harvard Graduate School of Business Administration suggested that the Securities Act of 1933 may serve to broaden the responsibility and liability of lawyers to the investing public. Professor Isaacs prophesied that the courts would come to place greater emphasis on an attorney's professional status than on the contractual relationship with his client as the basis for a formulation of his duties and liabilities. He foresaw no radical change in the attorney's responsibilities resulting from this shift, but predicted "a restatement of the attorney's answerability to the court and to society, and a reminder that he is not an ordinary employee of his client."1

There las been little occasion until recently for the courts to consider Professor Isaacs' suggestion as to the nature of the duties imposed upon lawyers by federal and state securities laws, or for the legal profession to respond. Generally, those cases in which courts have examined the duties of a lawyer in a federal securities law context have involved lawyers who also assumed duties as directors ${ }^{2}$ or else have involved the lawyer's active participation in a fraudulent sale of securities where rendition of professional services was imcidental to the scheme. $^{3}$ Courts that have considered a lawyer's responsibility just as

* Member of the California Bar.

This article is based on the author's presentation in a panel on "Liability of Lawyers and Accountants Under the Securities Laws" sponsored by the California Continuing Education of the Bar in October, 1972.

1. Isaacs, Liability of the Lawyer for Bad Advice, 24 CALIF. L. Rev. 39, 45-47 (1935).

2. Escott v. BarChris Constr. Corp., 283 F. Supp. 643 (S.D.N.Y. 1968); Feit v. Leasco Data Processing Equip. Corp., 332 F. Supp. 544 (E.D.N.Y. 1971); Blakely v. Ligae, CCH FED. SEc. L. REP. \ा 93,788 (D. Ore. 1972); SEC v. American Associated Systems, Inc., CCH FED. SEc. L. REP. If 94,089 (6th Cir. 1973). In Blakely v. Ligae, supra, an attorney-director was stated to have assumed a role beyond a lawyer's normal one in preparing a misleading prospectus and to be liable both as a lawyer and a director.

3. United States v. Benjamin, 328 F.2d 854 (2d Cir. 1964), cert. denied, 377 U.S. 953 (1964); Katz v. Amos Treat \& Co., 411 F.2d 1046 (2d Cir. 1969). 
a lawyer for assisting in an unregistered sale of securities have generally concluded that the lawyer could not be held liable for "participating" in the unlawful sale where he did no more than serve as counsel unless he was aware that the sale was unlawful. ${ }^{4}$ However, the district court's conclusion in Black \& Co. v. Nova-Tech, Inc., ${ }^{5}$ that a law firm nay be subject to suit because its name appears on a client's annual report, has provided the legal profession with an occasion to review and possibly restate for the public the obligations which are assumed by or imposed upon a lawyer as a consequence of his role in the preparation of the inultitude of documents disseminated by corporate clients. Similarly, the position taken by the Securities and Exchange Commission in the National Student Marketing Corporation complaint ${ }^{0}$

4. Nicewarner v. Bleavins, 244 F. Supp. 261, 266 (D. Colo. 1965); Hughes v. Bie, 183 So. $2 d 281$ (Fla. App. 1966); Adams v. American-Western Securitics, Inc., 3 CCH BlUE SKY L. REP. I 71,072 (Ore., May 17, 1973). See also Wonneman v. Stratford Sec. Co., '57-'61 CCH FeD. SEC. L. REP. II 91,034 (S.D.N.Y. 1961); SEC v. Spectrum, Ltd., CCH FED. SEc. L. REP. I 93,631 (S.D.N.Y. 1972).

5. 333 F. Supp. 468 (D. Ore. 1971). In Adams v. American-Western Securities, Inc., 3 CCH BLUE SKY L. REP. If 71,072 (Ore., May 17, 1973), the Oregon Supreme Court noted that the decision im Black was not binding on it, and that some of the statements in the opinion may be "overly broad" if literally applied.

6. Complaint, SEC v. National Student Marketing Corp., No. 225-72 (D.D.C., filed Feb. 3, 1972), '71-72 CCH FED. SEC. L. REP. I 93,360. In the National Student Marketing complaint the SEC alleged, inter alia, that proxy material concerning a merger between National Student Marketing Corp. (NSMC) and Interstate National Corp. (Interstate) which was sent to stockholders of both corporations to solicit approval of the transaction contained unaudited financial statements of NSMC which were materially false.

The merger agreement required that counsel for NSMC and Interstate deliver opinions to the effect that all steps taken to consummate the merger had been validly taken and that, to the knowledge of counsel, neither NSMC nor Interstate had incurred any violation of any federal or state statute or regulation. The SEC's complaint alleged that as part of a fraudulent scheme counsel for NSMC and Interstate

failed to refuse to issue their opinions ... . [required as a condition of closing] and failed to imsist that the financial statements be revised and sharelolders be resolicited, and failing that, to cease representing their respective clients, and, under the circumstances, notify the plaintiff Commission concerning the misleading nature of the nine month financial statements.

Id. at 93,913-17 \ा 48(i).

The coinplaint also charged counsel for NSMC with transmitting to the SEC a Form 8-K affirming the accuracy of the disputed financial statements, and charged counsel for NSMC and Interstate with dehvering certain other opinions allegedly based on facts which counsel knew or should have known were false. It should be kept in mind that to date none of the allegations in the SEC's complaint have been adjudicated on the merits. Some of the attorney defendants in this case brought a motion for sunmary judgment, which was denied. However, the question of attorney liability was not before the court, as the movants had conceded violations of the securities laws for the purposes of their motions and were simply urging that injunctive relief was not necessary under the circumstances. SEC v. National Student Marketing Corp., No. 105, Civil No. 225-72 (D.D.C., Mar. 21, 1973), CCH FeD. SEC. L. REP. II 93,820.

The National Student Marketing complaint has already been the subject of coinment. See, e.g., Karmel, Attorneys' Securities Law Liabilities, 27 Bus. LAw. 1153 (1972); Koch, Attorney's Liability: The Securities Bar and the Impact of National 
-that an attorney is obliged to report a client's alleged securities law violation to the Commission-has given the legal profession cause to reflect upon the question posed by Professor Isaacs: to whom are the securities lawyer's duties owed?

The purpose of this article is to re-examine in the light of existing decisions and emerging trends the responsibilities an attorney may properly be viewed as having assumed under federal and state securities laws and, indeed, the common law, in connection with the dissemination of corporate information to the public. The analysis will focus on the responsibilities which an attorney assumes in his capacity of attorney rendering professional services. An attorney may also assume other responsibilities by occupying an official position witl a corporation, for example, by becoming a corporate director. ${ }^{7}$ It has been suggested that in such cases the attorney's professional skills may justify requiring a higher degree of competence in office than if he were not so skilled. ${ }^{8}$ However, because the securities laws may under certaim circumstances impose specific obligations on directors and impose other obligations on attorneys acting as "experts," it is important for purposes of analysis to differentiate the attorney's separate roles. ${ }^{9}$

It is also useful to distinguish two basic functions which the attorney performs: that of delivering legal opinions explicitly identified as such in a prospectus or other disclosure document, and that of assisting a corporate client in the gathering and dissemination of factual information where the attorney does not expressly hold himself out as

Student Marketing, 14 WM. \& MaRY L. Rev. 883 (1973); Shipman, The Need for SEC Rules to Govern the Duties and Civil Liabilities under the Federal Securities Statutes, 34 OHro ST. L. J. 731 (1973); Comment, SEC Disciplinary Rules and the Federal Securities Laws: the Regulation, Role and Responsibilities of the Attorney, 1972 Duke L. J. 969; Note, Securities and Exchange Commission v. National Student Marketing Corp: The Attorney's Duty, 46 TEMP. L.Q. 153 (1972); Note, A New Ethic of Disclasure-National Student Marketing and the Attorney-Client Privilege, 48 Norre DAME LAw. 661 (1973); Freeman, Opinion Letters and Professionalism, 1973 DUKE L. J. 371.

7. A recent study of 511 manufacturing companies and 340 nonmanufacturing companies disclosed that law was the third most freqnently cited affiliation of outside directors. J. Bacon, Corporate Directorship Practices: Membership and COMMITTEES OF THE BoARD 29 (Conference Bd. Report No. 588 (1973)).

8. Address by then SEC Chairman G. Bradford Cook, The Director's Dilemma, Southern Methodist University School of Business Administration, April 6, 1973, $\mathrm{CCH}$ FED. Sec. L. REP. II 79,302, at 82,918 (1973); Folk, Civil Liabilities Under the Federal Securities Acts: The BarChris Case, 55 VA. L. Rev. 1, 33-37 (1969) [hereinafter cited as Folk].

9. More than one attorney may be on the board of directors or be otherwise connected with a corporation, but all may not assume identical responsibilities with respect to dissemination of corporate information. For example, the proxy statement for the 1973 Annual Meeting of Shareholders of IBM discloses four lawyers aniong the candidates for director, and one of them was also Vice President and General Counsel. 
an expert. Of course, in preparing legal opinions, the attorney may also need to gather factual information on which to base his opinion; and while assisting in the dissemination of factual information, the attorney may have to draw legal conclusions as to what information must be included in a disclosure document as "material." Nevertheless, the attorney may be viewed as playing a different role in the disclosure process when he acts as an expert in delivering an explicit legal opinion, for example, on the validity of an issuance of securities, than when he assists a client in verifying the accuracy of the factual portions of a registration statement, Form 10-K, annual report, or press release. Accordingly, the two functions will be considered separately in analyzing the duties assumed by the attorney and the persons to whom such duties are owed.

\section{I.}

\section{The AtTorney's ResponsibILITIES WhEN RENDERING EXPLICTT LEGAL OPINIONS}

\section{A. Securities Act of 1933}

The Securities Act of $1933^{10}$ expressly sets forth the responsibilities of certain persons involved in the disclosure process: officers of an issuer who must sign the registration statement, directors, underwriters, every accountant, engineer, appraiser, or other person whose profession gives authority to a statement made by him, ${ }^{11}$ and persons controlling any of the foregoing. ${ }^{12}$ The 1933 Act does not specifically identify the responsibilities of attorneys who participate in the disclosure process. However, Schedule A to the Securities Act of $1933^{13}$ and the various forms prescribed by the Securities and Exchange Commission (heremafter referred to as the "SEC") for registration of securities under the $\mathrm{Act}^{14}$ do require that an opinion of counsel on the validity of the securities be filed as an exhibit to the registration statement. Although the attorney is not expressly identified as an "expert" on whom liability may be imposed under section 11(a) (4), it is reasonable to assume with respect to his opinion on validity that he

10. 15 U.S.C. $\$ \S 77$-aa (1970) [hereinafter cited as 1933 Act].

11. 1933 Act $\S 11$ (a)(2)-(4), 15 U.S.C. $\S \S 77 \mathrm{k}(\mathrm{a})(2)-(4)(1970)$.

12. 1933 Act $\$ 14,15$ U.S.C. $\$ 770$ (1970).

13. Section 7 of the 1933 Act, 15 U.S.C. $\& 77 \mathrm{~g}$ (1970) and Schedule A, II 29, 15 U.S.C. $\$ 77 \mathrm{aa}$ (1970) provide that a copy of the opinion or opinions of counsel in respect to the legality of the issue shall accompany a registration statement filed under the 1933 Act.

14. See, e.g., Form S-1, Exh. 6; Form S-2, Exh. 6; Form S-3, Exh. 5; Form S-4, Exh. 4; Form S-5, Exh. 3; Form S-6, Exh. 3; Form S-7, Exh. 3; Form S-8, Exh. 3; Form S-9, Exh. 3; Form S-10, Exh. C; Form S-11, Exh. 6; Form S-12, Exh. 5; Form S-13, Exh. 3; Form S-14, Exh. 5; and Form S-16, Exh. 2. These forms are reproduced in 1 CCH FED. SEC. L. REP. II 7121-95. 
will be treated as a "person whose profession gives authority to a statement made by him" within the meaning of that section of the 1933 Act. ${ }^{15}$

In addition, issuer's counsel may, at the request of the underwriters or otherwise, assume the responsibility for rendering legal opinions in the registration statement on other aspects of the offering, as, for example, on tax consequences, on the status of the issuer's title to material properties, or on the posture of pending material litigation. In each instance in which counsel undertakes to render such an opinion, it appears that lie is acting as an expert within the meaning of section 11(a)(4) and thereby assuming the liabilities of an expert.

Where the attorney has expressed a legal opinion in a registration statement or prospectus filed under the 1933 Act, he may be held liable under section 11(a) to any person acquiring the securities covered by his opinion if it contains an untrue statement of a material fact, or omits to state a material fact required to be stated therein or necessary to make the statements therem not misleading. To avoid liability the attorney must sustain the burden of proof that, when the part of the registration statement made upon his authority becaune effective, he

\section{1933 Act $\$ 11(a)(4), 15$ U.S.C. $\$ 77 \mathrm{k}(\mathrm{a})(4)$ (1970) provides:}

Sec. 11. (a) In case any part of the registration statement, when such part became effective, contained an untrue statement of a material fact or omitted to state a material fact required to be stated therein or necessary to make the statements therein not misleading, any person acquiring such security (unless it is proved that at the time of such acquisition he knew of such untruth or omission) may, either at law or in equity, in any court of competent jurisdiction, sue... .

(4) every accountant, engineer, or appraiser, or any person whose profession gives authority to a statement made by him, who has with his consent been named as having prepared or certified any part of the registration statement, or as having prepared or certified any report or valuation which is used in connection with the registration statement, with respect to the statement in such registration statement, report, or valuation, which purports to have been prepared or certified by him.

With respect to what an opinion as to "validity" must cover, note that Exhibit 6 to Form S-1, for example, requires the attorney's legal opinion to indicate whether the securities will be legally issued, fully paid and nonassessable, and, if debt securities, whether they will be binding obligations of the registrant. Matters relating to assessability of stock and potential liability for debts to employees, see, e.g., N.Y. Bus. CORP. LAW $\$ 630$ (McKinney 1963), should be disclosed in the section of the prospectus describing the securities, since it is possible that the attorney will be deemed to liave "expertised" that portion of the prospectus within the meaning of section 11(a)(4). See also Fuld, Legal Opinions in Business Transactions-An Attempt to Bring Some Order out of Some Chaos, 28 Bus. LAw. 915, 932-34 (1973).

In connection with public offerings under the 1933 Act, connsel may be called upon to render "opinions" that in the course of their engagement no facts came to their attention which would render a registration statement or prospectus materially misleading or cause them to conclude that there are material omissions therein. Such "opinions" relate to the attorney's duty with respect to acquisition and dissemination of facts rather than to the attorney's more traditional function of rendering opinions as to matters of law, and will therefore be separately considered below. 
had reasonable grounds to believe and did believe, after reasonable investigation, that the statements in his opinion were true and complete. $^{18}$

Section 11(c) of the 1933 Act provides that in determining, for the purpose of paragraph (3) of section 11(b), what constitutes reasonable investigation and reasonable ground for belief, the standard of reasonableness shall be that required of a prudent man in the management of his own property. At least where an attorney is explicitly rendering an expert opinion in a registration statement, it appears that section 11 imposes essentially the same responsibility to exercise due care that has been imposed at common law on attorneys sued for malpractice on a tort theory of negligence. ${ }^{17}$

However, in two respects section 11 does appear to impose a leavier burden on the attorney than that imposed by common law. First, the attorney carries the initial burden of proving that he exercised due care, ${ }^{18}$ whereas at common law the burden of proving negligence normally falls on the plaimtiff. ${ }^{19}$ Second, section 11 makes it clear that the attorney's duty and his liability extend to all those who purchase the securities covered by the registration statement. In contrast, at common law an attorney has been traditionally viewed as owing a duty only to the specific client for whom he perforined his professional service. At least where the conduct is no more culpable than simple neghigence, recovery is not normally permitted those who claim to have relied on the attorney's opinion without a showing of privity. ${ }^{20}$

This limitation on the scope of an attorney's duties may reflect the courts' traditional reluctance in cases mvolving pecuniary rather than physical harm to impose what may be a crushing hability in favor of a potentially very large circle of plaintiffs which is out of proportion to the tortfeasor's conduct. Thus, in the leading case of Ultra-

16. 1933 Act $\S 11(\mathrm{~b})(3)(B), 15$ U.S.C. $\$ 77 \mathrm{k}(\mathrm{e})$ (1970). In addition, publication by the issuer of an earnings statement covering a period of twelve months beginning after the effective date of the registration statement will place upon the plaintiff the burden of proving reliance on the misrepresentation. 1933 Act $\S 11(\mathrm{a})$, 15 U.S.C. $\$ 77 \mathrm{k}(\mathrm{a})(1970)$.

17. See W. Prosser, Torts 161 (4th ed. 1971); 1 HARPER \& JaMes, The LaW or TORTS \$ 7.6, at 550-51 (1956); Isaacs, Liability of the Lawyer for Bad Advice, 24 CALIF. L. REv. 39 (1935); Wade, The Attorney's Liability for Negligence, 12 VAND. L. Rev. 755 (1959); Note, Attorney Malpractice, 63 CoLUM. L. REv. 1292, 1294-1307 (1963); Note, The Bases of the Attorney's Liability to His Client for Malpractice, 37 VA. L. Rev. 429 (1951); cf. Gagne v. Bertran, 43 Cal. 2d 481, 275 P.2d 115 (1954).

18. 1933 Act $\$ 11(\mathrm{~b})(3)(B), 15$ U.S.C. $\$ 77 \mathrm{k}(\mathrm{b})(3)$ (B) (1970).

19. W. PROSSER, TORTS 208-09 (4th ed. 1971).

20. Id. at 707-08; REsTATEMENT OF TORTS $\$ 552$ (1938); see also RestateMENT (SECOND) OF ToRTs $\$ 552$, comments a, $h$, $i$ and $j$ (Tent. Draft No. 12, 1965). 
mares Corp. v. Touche, Niven \& Co., ${ }^{21}$ Chief Judge Cardozo declined to hold that a firm of public accountants which certified the false financial statements of a rubber importer could be held hable on a theory of negligence to a factor who loaned funds to the importer in reliance on such statements. However, Judge Cardozo recognized that where the intended recipient of negligently prepared information is clearly known or identifiable, rather than a member of an indeterminate class, the injured recipient of the false information might even be deemed a third party beneficiary and entitled to relief for breach of a third party beneficiary contract. ${ }^{22}$ Furthermore, where the purveyor of false or misleading information is guilty of conduct approaching fraud rather than ordinary negligence, the class of plaintiffs might be broadened. ${ }^{23}$

A comparable analysis was applied in two California cases where intended benficiaries under a testator's will did not receive their expected inheritance because of an attorney's alleged negligence. In $\mathrm{Lu}$ cas $v$. $\mathrm{Hamm}^{24}$ the beneficiaries, although concededly not in privity with the drafting attorney, were permitted to state a claim on a theory of breach of a third-party beneficiary contract as well as a claim in tort for negligence. Their claims were ultimately denied because the court concluded that the attorney would not be held liable for an error as to a question of law on which well-informed practitioners may entertain reasonable doubt. In Heyer v. Flaig, ${ }^{25}$ intended beneficiaries of a testatrix who planned to remarry shortly after executing her will were permitted to state a claim against the drafting attorney based on his failure to take into account the rule permitting a spouse not mentioned in a will to participate in the estate.

The California cases make it clear that in determining the class of persons who may assert common law liability against an attorney although not in strict privity with him, a court inust balance various factors, imcluding the extent to whicli the transaction was intended to affect the plaintiff, the foreseeability of harm to him, the degree of cer-

21. 255 N.Y. 170,174 N.E. 441 (1931).

22. Id. at 184, 174 N.E. at 445; accord, Glanzer v. Shepard, 233 N.Y. 236, 135 N.E. 275 (1922). Where the plamtiff is a member of an indeterminate class, it is questionable whether under traditional theories of third-party beneficiary contracts it can be said that he and all other members of the class were intended to be benefited. See 2 S. Williston, Contracts $\$ \S 356$ A, 378 (3d ed. 1959).

23. In Ultramares the court recognized that the accountants should be held liable if their conduct amounted to fraud, and that issuing a certificate without knowledge of facts sufficient to permit such certification could itself be evidence of fraud. The willingness of courts to extend the scope of liability for intentional misrepresentations lias been well recognized. See REsTatement of TorTs $\$ 536$ (1938).

24. 56 Cal. 2d 583, 364 P.2d 685, 15 Cal. Rptr. 821 (1961), cert. denied, 386 U.S. 987 (1962).

25. 70 Cal. 2d 223, 449 P.2d 161, 74 Cal. Rptr. 225 (1969). 
tainty that the plaintiff suffered injury, the closeness of the connection between the defendant's conduct and the injury suffered, the moral blame attached to the defendant's conduct, and the policy of preventing future harm. ${ }^{26}$ This balancing process would probably produce the same results reaclied in the Ultramares case, since in Lucas and Heyer the claimants were clearly intended beneficiaries of the attorney's work and were inembers of a small, clearly defined class, whereas in Ultramares the plaintiff lender was but one of an unlimited class of persons who might liavc access to the issuer's fimancial statements and was inucli less clearly an intended beneficiary of the accountant's labor. ${ }^{27}$

Attorneys are often called upon to render opinions pertaiming to the sale of securities in a variety of 1933 Act situations wliere a section 11 registration statement is not involved. For example, an attorney may be required to express an opinion on whether securities are validly issued in connection with a Regulation $\mathrm{A}$ offering, ${ }^{28}$ an intrastate offering, ${ }^{29}$ a private placeinent, ${ }^{30}$ or an offering of exempt securities. ${ }^{81}$ He may also be required to decide whether a particular sale of securities constitutes a private placement exempt from registration under section 4(2) of the 1933 Act, or whether a particular resale of securities is

26. Id. at 227,449 P.2d at 164,74 Cal. Rptr. at 228 . See also Biakanja v. Irving, 49 Cal. 2d 647, 649, 320 P.2d 16, 19 (1958) (liability of notary public); Lucas v. Hamm, 56 Cal. 2d 583, 588, 364 P.2d 685, 687, 15 Cal. Rptr. 821, 823 (1961), cert. denied, 386 U.S. 987 (1962). In these cases the court emphasized the inability of the person harmed by the defendant's negligence to obtain relicf from anyone other than the defendaut. This problem does not exist in the typical securities case where the attorney is at best a collateral participant in the transaction and the injured party can normally sue the issuer of securities or dispenser of the disclosure document.

27. When the intended beneficiary of the accountant's labor is clearly recognizable, some courts are prepared to hold the accountant liable for negligent preparation of his report to one not in privity with him. See, e.g., Rhode Island Hosp. Trust Nat'1 Bank v. Swartz, Bresenoff, Yauner \& Jacobs, 455 F.2d 847 (4th Cir. 1972); Rusch Factors, Inc. v. Levin, 284 F. Supp. 85 (D.R.I. 1968); Ryan v. Kanne, 170 N.W.2d 395 (Iowa 1969); Shatterproof Glass Corp. v. James, 466 S.W.2d 873 (Tex. Civ. App. 1971). Although these cases questioned the Ultramares decision, the factual setting presented were such that Chief Judge Cardozo's court inight well have imposed liability under the theory of Glanzer v. Shephard, 233 N.Y. 236, 135 N.E. 275 (1922). The cases involving the necessity of showing privity to hold an accountant liable for negligence are collected in Annot., 46 A.L.R.3d 979, 989 (1972).

28. 1933 Act $\S 3(\mathrm{~b}), 15$ U.S.C. $\$ 77 \mathrm{c}(\mathrm{b})(1970)$ and Regulation A adopted thereunder, 17 C.F.R. $\$ \$ 230.251-.263$ (1972).

29. 1933 Act $\$ 3(\mathrm{a})(11), 15$ U.S.C. $\$ 77 \mathrm{c}(\mathrm{a})(\mathrm{n})(1970)$.

30. 1933 Act $\S 4(2), 15$ U.S.C. $\S 77 \mathrm{~d}(2)$ (1970), provides that section 5 of the 1933 Act does not apply to "transactions by an issuer not involving any pnblic offering."

31. 1933 Act $\& 3(\mathrm{a}), 15$ U.S.C. $\& 77 \mathrm{c}(\mathrm{a})$ (1970), exempts froin the 1933 Act several types of securities, including mumcipal bonds, securities issued by coinmon carriers subject to ICC jurisdiction, and securities issued by banks. 
permissible under Rule 144 or 145, or former Rule $133 .^{32}$ The 1933 Act does not specify the standard of care by which the attorney's conduct is to be measured under such circumstances or the class of potential plaintiffs to whom the attorney may be liable. Simce there is no reason to lower the standard of care from that applied in a non-securities law context, an attorney should at least be held responsible to the client for whom lie prepares a legal opinion as to the due issuance of securities or the nonapplicability of the 1933 Act if he acts negligently. However, without the assistance of section 11 the plaintiff would normally be expected to have the burden of proof in the case. A difficult question is whether, absent section 11, the class of plaintiffs sliould be broadened to include persons not in privity with the attorney, and here we must return to the policy questions discussed in Ultramares and Lucas.

Where the attorney has permitted his opinion to be included in an offering circular for the express purpose of inducing a rather clearly defined class of potential investors to purchase a portion of the initial offering for a fixed price at a given time, it is reasonable to conclude as a matter of statutory policy that one who does so purchase should not be excluded from the class of potential plaintiffs simply because the offering is for less than $\$ 500,000$ or is intrastate or private in nature. However, absent an express statute such as section 11 of the 1933 Act, an attorney's liability for negligent statements in his opinion should not be extended to the imprecise and potentially much larger class of persons who engage in after-market trading over an extended period of time and at varying prices, or who utilize an offering circular for some other purpose (e.g., to extend credit to the issuer).

The attorney's opinion on the validity of securities or the tax consequences of a transaction, for example, is normally intended to affect only the potential investor's decision in connection with the immediate stock issuance. Persons who use the opimion for other purposes may take risks that are not foreseeable, and proof of causation other than a bare assertion of reliance will often be extremely difficult to sustain. Since the attorney error hypothesized is no more than neg-

32. A question might be posed as to when an attorney has in reality delivered an explicit opiniou. In Black \& Co. v. Nova-Tecl, Inc., 333 F. Supp. 468 (D. Ore. 1971), the United States District Court lield that a firm of attorneys could be subject to service as participants in an alleged sale of securities in violation of the Oregon Blue Sky Law since they liad authorized the issuer to include their firm's name in the annual reports, used in connection with the sale. If an attorney is to be leld liable to anyone for delivery of an explicit opinion, it should be clearly slown that an opinion was in fact delivered and liability should be restricted to the matters covered by the opinion. The nuere reference to counsel in a document should not be construed as evidence that counsel has rendered an opinion on any of the contents of the document except as indicated therein. 
ligence, his moral blame is smaller than in cases of reckless conduct, and since recovery by those clearly entitled to rely on the attorney's opinion may itself be very large, the threat of that liability alone should deter careless conduct. Admittedly, balancing these factors produces a closer result where it is intended or can reasonably be expected that subsequent investors will rely on the attorney's opinion. An opinion as to the tax-exempt status of municipal bonds which accompanies the bonds might arguably fall within this category. Therefore, to avoid having a court strike a balance that broadens the class of persons to whom an attorney is liable beyond those to whom his opinion is initially delivered, the attorney who is delivering such an opinion should consider expressly limiting the persons entitled to rely thereon. ${ }^{38}$ Where the disclosure document in which the attorney's opinion appears is not one normally distributed for the purpose of inducing action, as, for example, an annual report, it slould not be necessary for the attorney expressly to limit his opinion in such fashion. ${ }^{34}$

When an attorney knows that his opinion is being utilized to effect a sale of securities unlawful under the 1933 Act, or does not undertake the inquiry necessary to permit limi to express an honest and informed opinion that the sale is exempt from registration, or is in possession of facts which would cause a prudent lawyer to make further inquiry, or otherwise acts in a reckless manner, his degree of culpability may suggest that the balance be struck in favor of holding him liable to a larger class of plaintiffs.

When the broader class of plaintiffs constitutes the general public, represented by the Department of Justice in a criminal proceeding or by the SEC in a suit for injunctive relief, the recent case of SEC $v$. Spectrum, Ltd. suggests that a showing of greater culpability than simple negligence will be required if the attorney is to be charged with "aiding and abetting" a violation of the securities laws by someone else. $^{85}$ In that case, the court rejected the claim of the SEC that an

33. In many cases where section 11 is not applicable, the attorney may be in a position to limit the class of persons who can claim to rely on his opinion by expressly providing therein that it is not to be communicated to or rehed npon by anyone other than the immediate recipient. Cf. Escott v. BarChris Constr. Corp., 283 F. Supp. 643, 698 (S.D.N.Y. 1968) (accountants' liability so limited).

34. Most 1934 Act disclosure documents (e.g., Form 8-K, 10-Q, and 10-K) are not viewed as being distributed to stockholders for the purpose of imducing a change in position. Gerstle v. Gamble-Skogmo, Inc., Nos. 72-2259 \& 72-2345 (2d Cir., May 9 1973), CCH Fed. Sec. L. REP. II 93,983, at 93,941 n.18. This may not necessarily be the case, however, where such documents are incorporated by reference in a Form S-16 registration statement under the 1933 Act.

35. SEC v. Spectrum, Ltd., 71 Civ. 1497 (S.D.N.Y., Oct. 10, 1972), '72.73 CCH FED. SEC. L. REP. Tा 93,631. Injunctive relief should not necessarily require proof of a higher degree of culpability. See, e.g., cases cited in note 58 infra, which suggest that injunctive rehef may not require a showing of as high a degree of culpabihity as does re- 
attorney should be held hable for aiding and abetting a violator of the 1933 Act through delivery of an opinion permitting an unregistered distribution, unless it could be shown that he knew or, on the basis of facts whiclı would have put a reasonable man on notice, should have known that the transaction was unlawful. Similarly, if scienter can be shown, hability under the 1933 Act may be imposed on a theory of participation under section 12(2) of the 1933 Act even in the absence of privity. ${ }^{36}$ Where concepts of aiding and abetting and participation are utilized to expand the class of persons protected in cases involving conduct more culpable than ordinary negligence, the result is consistent with the approach heretofore taken by the courts in both securities and non-securities law contexts to broaden the class of plaintiffs to whom a tortfeasor will be held liable for intentional or reckless misrepresentations. ${ }^{37}$ When the attorney has not made an investigation sufficient to permit the good faith rendition of an opinion, or when he is on notice of facts which, if inquired into, would disclose that he could not render an opinion, he may be guilty of such recklessness that his activities should be proscribed even if he was not a conscious or knowing participant in a violation of law. Such a result finds some support in the recent authority. ${ }^{38}$

On the other hand, the uncritical application of such concepts as aiding and abetting and participation could lead to imposition of liability

covery of damages. On the other hand, where the SEC seeks equitable relief against an attorney individually, the Commission must beheve that the alleged violation involves sufficient culpability to warrant enjoining future violations. Since the decree may then be made the basis for administrative proceedings against the attorney leading to suspension of his right to practice before the Commission unless the violation is found not to have been willful, Rule 2(e), 17 C.F.R. $\$ 201.2(\mathrm{e})(1972)$, the result reached in the Spectrum case appears sound.

36. Lanza v. Drexel \& Co., No. 35794 (2d Cir., Apr. 26, 1973), CCH Fed. SEC. L. REP. I 93,959; Folk, supra note 8, at 202. Note that section 12(2) of the 1933 Act, 15 U.S.C. $\$ 77 l(2)(1970)$, applies to securities and transactions exempt under sections 3 and 4, 15 U.S.C. $\$ \$ 77$ (d) and (e) (1970), except with respect to securities covered by section 3(a)(2), 15 U.S.C. $\$ 77 c(a)$ (2) (1970). In SEC v. Spectrum, Ltd., 71 Civ. 1497 (S.D.N.Y., Oct. 10, 1972), '72-73 CCH FED. SEC. L. REP. If 93,631, the court rejected the SEC's contention that simply by virtue of preparation of an opinion letter, an attorney becomes an underwriter within the meaning of section 2(11) of the 1933 Act as a participant in the distribution of securities to the public.

37. See Ultramares Corp. v. Touche, Niven \& Co., 255 N.Y. 170, 174 N.E. 441 (1931); Restatement OF TorTs $\& 536$ (1938). The proposed Federal Securities Code takes a slightly different approach by extending the class of plaintiffs who may sue on the basis of a false registration statement, offering statement, or report, but limiting the amount of damages assertable unless misrepresentation was made with knowledge by the particular defendant. Only the registrant and knowing aiders and abetters are liable for other false filings. Federal. Securities Code $\$ \S 251$ A, 1403-04 (ALI Tent. Draft No. 2, March, 1973) [hereinafter cited as Fed. SEc. CoDE].

38. See, e.g., Lanza v. Drexel \& Co., No. 35794 (2d Cir., Apr. 26, 1973), CCH Fed. Sec. L. Rep. If 93,959; Chris-Craft Indus., Inc. v. Bangor Punta Corp., No. 72 1064 (2d Cir., March 16, 1973), CCH FEd. SEc. L. Rer. \ 93,816. 
on the basis of little more than a "but for" test (e.g., but for the delivery of an attorney's opinion, the transaction would not have been consummated). The adoption of such a simplistic causation test could result in discarding the balancing process described above, and the imposition of liability without regard to either privity or degree of culpability. At least two thoughtful commentators have recently urged that in applying such doctrines as aiding and abetting and participation, a finding of knowing or conscious participation in a violation of law be required. ${ }^{30}$ Where liability is sought to be based on participation in a violation of the securities laws (rather than negligent preparation of an explicit legal opimion), it is reasonable to require a showing of knowledge or at least facts which would put one on notice of a need to inquire further.

Whatever standard of responsibility is required of attorneys preparing opinions in the securities area, the question still remains as to what level of verification of the facts supporting his opinion must be undertaken by the attorney in order to establish his due diligence. Any standard should require an attorney to review the statutes of the state of incorporation, as well as the articles of incorporation, the by-laws, and minutes of board ineetings relevant to a new issue of capital stock to verify, inter alia, that the issuer has been duly organized, that adequate capital stock of the class or series to be issued has been authorized, that its issuance has been authorized, and that the existing shareholders are not entitled to assert pre-emptive rights with respect thereto. On the other hand, the attorney should be entitled to rely on a representation froin the issuer's responsible officers or its transfer agent and upon certificates of governmental agencies as to certain facts which may form the basis for his opinion. For example, the attorney should not be required to verify personally the number of shares of a class issued and outstanding to determine whether sufficient authorized shares remain available to support a conteinplated issue. Similarly, in delivering an opinion that shares are full paid and nonassessable, he slould be able to rely on the issuer's financial statements or its officers for verification as to whether consideration of the type and amount specified to be received for shares was in fact collected. He should also be able to rely upon certificates of governmental officials as to the issuer's good standing and the fact that it has paid applicable state taxes which affect its good standing.

It may be that no single test can be stated as to when a lawyer has a duty to verify facts independently. However, the existence of certain criteria may justify rehance upon others to verify facts: first,

39. Folk, supra note 8, at 206; Ruder, Multiple Defendants in Securities Law Fraud Cases: Aiding and Abetting, Conspiracy, In Pari Delicto, Indemnification and Contribution, 120:2 U. PA. L. REv. 597, 620-38 (1972). This is also the view of the proposed Federal Securities Code. FED. SEC. CoDE, supra note 37, \$ 1418(b). 
the extent to which those special skills acquired through legal training and experience are not required for the investigation; second, the degree to which the facts in question fall within the ordinary business knowledge of the officers of the issuer or a third party upon whoin the attorney is relying. This latter consideration is related to a third criterion, the apparent reliability of the information source. For example, an attorney should be entitled to rely on public records or on documents required to be maintained by the issuer or a third party-as an example, stock transfer records. Finally, a fourth criterion is the extent to which the factual information has been assembled or verified by a representative of another responsible profession.

When the attorney's opinion has dealt with an unsettled question of law, the courts have been reluctant to hold the attorney liable at common law as an insurer of the soundness of his opinions. ${ }^{40}$ The same result should obtain under the securities laws when the attorney is required to express an opinion on an uncertain question, provided investors who will be relying on the opinion are at least apprised in the prospectus that uncertainties exist, if such be the case.

\section{B. Securities Exchange Act of 1934}

As implemented by the SEC, the Securities Exchange Act of 1934 establishes a comprehensive requirement of "continuous disclosure" for publicly held compamies which fall within the registration requirements of section 12 of that Act. Section $12^{41}$ requires issuers having total assets exceeding $\$ 1,000,000$ and a class of equity securities held of record by 500 or more persons, or a class of whose securities is listed on a national securities exchange, to register by filing a Form 10 or 12 registration statement. ${ }^{42}$ Issuers subject to section 12 must file periodic reports under section $13,{ }^{43}$ including quarterly reports on Form 10-Q and annual reports on Form $10-\mathrm{K}$, as well as monthly reports on Form 8-K where the types of events specified in that form have occurred. ${ }^{44}$ Under section $14,{ }^{45}$ issuers subject to section 12 also

40. Lucas v. Hamm, 56 Cal. 2d 583, 591, 364 P.2d 685, 689, 15 Cal. Rptr. 821, 825 (1961), cert. denied, 386 U.S. 987 (1962); Wade, The Attorney's Liability for Negligence, 12 VAND. I. REv. 755, 763 (1959); Note, Attorney Malpractice, 63 ColUM. L. Rev. 1292, 1299 (1963). Compare the attorney's obligation to research a problem to determine whether the answer is unclear. Smith v. Lewis, 31 Cal. App. 3d 677, 686, 107 Cal. Rptr. 95, 101 (1973).

41. 15 U.S.C. \$ 781 (1970) [The Securities Exchange Act of 1934 is lereinafter cited as 1934 Act].

42. 17 C.F.R. $\S \S 249.210,249.212$ (1972).

43. 15 U.S.C. $\$ 78 \mathrm{~m}$ (1970). An offering under the 1933 Act may subject an issuer to the periodic reporting requirements of the 1934 Act by reason of section 15(d) of the 1934 Act, 15 U.S.C. \& 780(d) (1970).

44. Form $8-\mathrm{K}$ is a mouthly reporting form required to be filed within ten days 
must submit proxy or information statements complying with the requirements of Regulation $14 \mathrm{~A}$ or $14 \mathrm{C}^{46}$ in connection with matters as to which shareholders are requested to take action, whether or not proxies are solicited. The purpose of these registration and periodic reporting forms, as revised and expanded by the Commission in recent years, is to provide continuous disclosure of information concerning publicly held companies comparable in scope to that in a registration statement under the 1933 Act.

However, unlike section 11 of the 1933 Act, the 1934 Act contains no provision expressly establishing an affirmative duty of due diligence on directors or other signatories of the documents required to be filed under sections 12,13 or 14 of the 1934 Act, nor on any experts whose opinions may be included therein. With respect to documents filed under the 1934 Act, section 18(a) ${ }^{47}$ establishes a much less stringent standard of responsibility by permitting a person sued to assert the defense that he acted in good faith and had no knowledge that a statement in a disclosure document was false or misleading. Section 18(a) would accordingly appear to require some showing of

after any month in which material events occur, including changes in control of the issuer, inaterial acquisitions or dispositions of assets, initiation of material legal proceedings, changes in outstanding securities, changes in the security for registered sccurities, defaults upon senior securities, increases or decreases in the amount of securities outstanding in excess of specified amounts, granting of options to purchase securities in excess of specified amounts, provision for material losses and similar events, and submission of matters to vote of security holders. Form 10-Q must be filcd within 45 days after the end of each fiscal quarter of an issuer, other than the fourth quarter, and must set forth certain summarized financial information as to sales, profits and loss for the current year and the preceding year, and capitalization and stockholders' equity. Form $10-\mathrm{K}$ is an annual report, to be filed within 90 days after the end of the registrant's fiscal year, setting forth information which, together with information contained in any proxy solicitation material transmitted under the 1934 Act, serves to update 1933 Act and 1934 Act (Form 10) registration statcments.

45. 15 U.S.C. $\& 78 \mathrm{n}(1970)$.

46. 17 C.F.R. $\$ \$ 240.14 a-1$ to $-12,240.14 c-1$ to -7 (1972).

47. 15 U.S.C. $\$ 78 \mathrm{r}(1970)$. Section 18(a) provides that:

Any person who shall make or cause to be made any statement in any application, report, or document filed pursuant to this chapter or any rule or regulation thereunder or any undertaking contained in a registration statement as provided in subsection (d) of section 15 of this Title, which statenuent was at the time and in the light of the circumstances under which it was made false or misleading with respect to any material fact, shall be liable to any person (not knowing that such statemeut was false or misleading) who, in reliance upon such statement, shall have purchased or sold a sccurity at a price which was affected by such statement, for damages caused by such reliance unless the person sued shall prove that he acted in good faith and had no knowledge that such statement was false or misleading.

One court has leld that section 18(a) is the exclusive remedy for violations of section 13 (a) of the 1934 Act and that there is no private right of action implied under section 13(a) as to misstatements or omissions in filings made under that section. In re Penn Cent. Sec. Litigation, No. 56 (E.D. Pa., Oct. 16, 1972), CCH Fed. SEc. L. RRP. II 93,980. But see Heit v. Weitzen, 402 F.2d 909 (2d Cir. 1968). 
knowledge or scienter as a basis for liability. Furthermore, the plaintiff must show detrimental reliance on the document filed. Therefore, section 18(a) cannot be viewed as a fruitful basis for asserting liability under the 1934 Act. $^{48}$ To date, plaintiffs have more frequently used section 10(b) and Rule 10b-5 promulgated by the SEC thereunder, ${ }^{49}$ or section $14(a)^{50}$ in seeking to establish liability based on 1934 Act disclosure documents.

In view of the recent adoption of Rule 145, which treats a merger proxy statement as a 1933 Act registration statement, and Form S-16, whicl incorporates by reference the 1934 Act disclosure documents, we may expect to see increasing application of the diligence standards of section 11 of the 1933 Act to these documents. Such a development may simply anticipate the standards suggested in the proposed Federal Securities Code. ${ }^{\text {11 }}$

In formulating a standard for attorney's responsibility with respect to 1934 Act documents in which, or in colmection with which, he renders an explicit legal opinion, it should be noted that under the existing statutory and regulatory pattern there are few occasions when the attorney will be asked to deliver such an opmion. Form S-14 (whicl in effect is also a 1934 Act disclosure docuinent insofar as it constitutes a proxy statement) requires the filing of a legal opinion regarding the validity of securities issued in connection with a merger;52 Form S-16 (which incorporates therein 1934 Act disclosure documents by reference) requires an opinion as to the validity of securities covered by it. However, neither sections 12 or 13 of the 1934 Act, nor the forms promulgated thereunder, require the filing of an opinion of counsel, or provide for disclosures with respect to which an attorney must deliver an opinion. ${ }^{53}$ Occasionally an attorney may render an opimion on a matter other than the validity of securities which is reflected in a 1934 Act document, for example, an opinion concerning pending litigation or the validity of patents or titles to properties, or the tax consequences of a merger transaction. It is also conceivable that an attorney's opinion contained in a 1933 Act prospectus might be claimed to afford a basis for liability under the 1934 Act, at least where it is

48. Cf. Sommer, The Annual Report: A Prime Disclosure Document, 1972 DUKE L.J. 1093, 1102-04.

49. 1934 Act $\S 10(\mathrm{~b}), 15$ U.S.C. $\& 78 \mathrm{j}(\mathrm{b})$ (1970); Rule 10b-5, 17 C.F.R. $\S$ 240.10b-5 (1972).

50. 15 U.S.C. $\S 78 n$ (a) (1970).

51. FED. SEC. CODE, supra note 37, at 69-193.

52. Form S-14, Exh. 3.

53. Compare the attorney's position with that of the accountant, who must certify financial statements in the Form 10 Registration Statement, the Form 10-K Annual Report, and sometimes in Item 10 of Form 8-K. 
used with his consent for the purpose of inducing a change in position. ${ }^{54}$

In a transaction subject to Rule 145 , or pursuant to a Form S-16 registration statement, the express standards of section 11 of the 1933 Act should apply to any explicit legal opinions contained in the proxy statement or in the 1934 Act documents incorporated by reference in the Form S-16. Concerning situations in which section 11 is not inade expressly applicable, a more difficult question is posed. Generally, it would seem questionable to allow a lesser standard of care in delivering explicit legal opinions in such cases when the group of potential plaintiffs who may rely on the 1934 Act disclosure document is not a clearly defined class to whom the document was directed for the purpose of inducing action. However, in the absence of a showing of soinething more than ordinary negligence, the attorney's scope of responsibihity should not extend to the general investing public or to any other persons (sucli as lenders or suppliers) who might utilize an issuer's periodic reports as sources of information, for the reasons noted above in connection with opinions delivered in 1933 Act transactions not subject to section 11.

Such a result would be consistent with the position recently taken by the Second Circuit in Gerstle v. Gamble-Skogmo, Inc. ${ }^{\text {b5 }}$ a case arising under 14(a) of the 1934 Act prior to the adoption of Rule 145. The court in that case required a showing of no more than ordinary negligence to establish liability against the corporation responsible for circulating a proxy statement determined to be materially misleading. The court recognized that the existence of privity may bear heavily on the appropriate standard of culpability, but concluded that where the plaintiffs represented the very class of persons asked to approve a merger on the basis of a misleading proxy statement, and were seeking compensation from the beneficiary who was responsible for the preparation of the statement, they were not required to establish any evil motive or even reckless disregard of the facts. The court of appeals was careful to limit its conclusions in the Gamble-Skogmo case to the rights assertable against the corporation benefitting froin the transaction by persons who were invited by proxy statement to participate in the taking of corporate action involving a change in the character of their securities. The opinion specifically did not address

54. Persons relying on a defective 1933 Act prospectus when purchasing securities otherwise than through the public offering may have a cause of action under Rule 10b-5. See Fischman v. Raytheon Mfg. Co., 188 F.2d 783 (2d Cir. 1951); Lanza v. Drexel \& Co., No. 35794 (2d Cir., Apr. 26, 1973), CCH Fed. Sec. L. Rep. II 93,959 (2d Cir. 1973).

55. Nos. 72-2259 \& 72-2345 (2d Cir., May 9, 1973), CCH Fed. SEc. L. Rep. II 93,983 . 
the question of the rights of persons who traded because of information in the proxy statement, on whom the statement would seem to have the same impact as an annual report to stockholders, nor did it address the principles that should govern liability of directors and other individuals having some responsibility for such a statement, as distinguished from the liability of a controlling corporation which has been the beneficiary of the action that was induced. ${ }^{56}$ Moreover, the court was careful to point out that most 1934 Act disclosure documents filed under section 18(a) of the 1934 Act (e.g., Form 8-K, $10-\mathrm{Q}$, and $10-\mathrm{K})$ are not distributed to stockholders for the purpose of inducing a change in position, and that a different standard of culpability might well be applied in actions concerning misrepresentations in proxy statements which are so distributed than in those involving reports which are merely filed with the Commission. ${ }^{57}$

The Second Circuit's position in Gamble-Skogmo implicitly reflects the judicial concern enunciated by Judge Cardozo in the Ultramares case-that hability out of all proportion to the conduct intended to be proscribed should not be visited on a defendant who is not the direct beneficiary of a transaction, in favor of a plaintiff who is not a inember of a defined class to wholn a communication is directed for the purpose of inducing action, unless culpability greater than ordinary negligence is shown. Some courts have reflected the same concern in permitting a showing of a lesser degree of culpability in a suit for injunctive relief where no damages are to be imposed. ${ }^{58}$ The proposed Federal Securities Code mirrors similar concerns in allowing unlimited assertion of liability only in the case of fraudulent knowledge or reckless conduct, and restricting recoveries in cases of ordinary neghigence by imposing an arbitrary statutory maximum on recovery. ${ }^{59}$

However, the courts are presently in disagreement as to the standard of diligence to be applied under the various provisions of the 1934 Act, particularly under Rule 10b-5. A majority of the Second Circuit presently requires a showing of scienter under Rule $10 \mathrm{~b}-5$, due to the concern that without such a requirement the rule might be invalid as exceeding the Commission's authority under Section 10(b) of the 1934

56. Id., CCH FED. SEC. L. REP. at 93,940 n.16.

57. Id., CCH FED. SEC. L. REP. at 93,941 n.18.

58. Mutual Shares Corp. v. Genesco, Inc., 384 F.2d 540, 547 (2d Cir. 1967); SEC v. Capital Gains Research Bureau, Inc., 375 U.S. 180, 193 (1963). Concern about disproportionate liability to a huge number of plaintiffs may also have been an underlying factor motivating a court recently to deny maintenance of a class action for damages while suggesting that a class suit for injunctive relief might be appropriate. Eisen v. Carlisle \& Jacquelin, No. 72-1521 (2d Cir., May 1, 1973), CCH FED. Sec. L. REP. If 93, 963, at 93, 864 n.28.

59. Fed. SEC. CODE, supra note $37, \S 1403(\mathrm{~g})$. 
Act to regulate "manipulative or deceptive devices." agreement on when scienter is present, however, and at least two and possibly four of the ten judges on the Second Circuit would vote for a lesser standard of culpability. ${ }^{61}$ Other courts have tended to view the standard of diligence as one something akin to a negligence standard or perhaps something even less. ${ }^{62}$

Inasmuch as an assessment of hability requires both a determination of the appropriate standard of care and the appropriate class of plaintiffs for rehief, the matter cannot be resolved by simple application of a negligence or scienter standard. Certainly there are valid social reasons for loolding an attorney to a duty of ordinary professional care when dehivering an exphicit legal opinion, and not requiring a showing of scienter. However, in determining the class of plaintiffs to whom the attorney will be held responsible, care must be taken to limit the class to those to whom the opinion in question was intentionally directed for the purpose of inducing action. If such a test is adopted, there will probably be few cases in which an attorney will be held responsible for his explicit opinions in publicly disseminated 1934 Act disclosure documents which are not already subject to section 11 of the 1933 Act by reason of Rule 145 or the provisions of Form S-16.

The attorney is not expressly named as a person who may be sued under the 1934 Act (except possibly as one who has filed a document under section 18(a)). Therefore, if he is held liable for his explicit opinions under the 1934 Act, he will probably be cliaracterized as a "collateral" rather than a principal defendant and lield responsible as a participant or aider and abettor. ${ }^{63}$ The second circuit has followed the view that such a collateral defendant must be found to have engaged in conduct more culpable than simple negligence. ${ }^{64}$ However,

60. Gerstle v. Gamble-Skogmo, Inc., Nos. 72-2259 \& 72-2345 (2d Cir., May 9, 1973), CCH FED. SEC. L. REP. $\{93,983$, at 93,941 .

61. Lanza v. Drexel \& Co., No. 35794 (2d Cir., Apr. 26, 1973), CCH Fed. Sec. L. REP. \ 93,959 at 93,842 (Hays, J., concurring in part and dissenting in part) and at 93,844 (Timbers, $\mathrm{J}$, concurring in part and dissenting in part).

62. Mitchell v. Texas Gulf Sulphur Co., 446 F.2d 90, 102 (10th Cir. 1971), cert. denied, 404 U.S. 1004 (1971) and 405 U.S. 918 (1971); Ellis v. Carter, 291 F.2d 270, 274 (9th Cir. 1961); Royal Air Properties, Inc v. Smith, 312 F.2d 210, 212 (9th Cir. 1962); City Nat'l Bank of Fort Smith, Ark. v. Vanderboom, 422 F.2d 221, 229-30 (8th Cir. 1970), cert. denied, 399 U.S. 905 (1970); Vanderboom v. Sexton, 422 F.2d 1233, 1239 (8th Cir. 1970), cert. denied, 400 U.S. 852 (1970). But see discussion of cases in Kohn v. American Metal Climax, Inc., 458 F.2d 255, 279-88 (3d Cir. 1972) (Adams, J., concurring and dissenting).

63. Cf. Lanza v. Drexel \& Co., No. 35794 (2d Cir., Apr. 26, 1973), CCH Fed. SEc. L. REP. ๆ 93,959, at 93,819; Chris-Craft Indus., Inc. v. Bangor Punta Corp., No. 72-1064 (2d Cir., Mar. 16, 1973), CCH FED. SEc. L. REP. If 93,816, at 93,510; see also Ruder, Multiple Defendants in Securities Fraud Cases: Aiding and Abetting, Conspiracy, In Pari Delicto, Indemnification, and Contribution, 120:2 U. PA. L. Rev. 597, 630-38 (1972).

64. Lanza v. Drexel \& Co., No. 35794 (2d Cir., Apr. 26, 1973), CCH Fed. 
other courts have not adopted such a stringent view, and some have utilized language that literally suggests the collateral defendant may be held liable without any knowledge whatsoever. ${ }^{65}$ As noted earlier, courts should not fall into the habit of blindly applying labels or catchwords which result in liability in the event that the transaction would not have occurred "but for" the attorney's involvement. Sound social policy may suggest holding professionals such as attorneys to a higher standard of diligence than one which requires a showing of scienter to establish liability. However, one need not conclude that liability may be imposed vicariously and without any showing of culpability in favor of anyone who may have chanced upon the attorney's opinion.

\section{II.}

\section{THE ATTORNEY's RESPONSIBILITIES WHEN Not RENDERING ExPLICIT LEGAL OPINIONS}

The skills an attorney brings to bear for a client in the acquisition and dissemination of infornation in the securities field are of equal if not greater importance to the business community than his function of delivering opinions on securities law matters. The attorney should be deeply involved in determining what factual infornation is to be included in registration statements utilized for offerings under the 1933 Act. Indeed, decisions on "materiality" often require his advice. $\mathrm{He}$ should similarly be involved in the preparation of registration statements, proxy statements and periodic reports filed under the 1934 Act, and those press releases and annual reports which are not required to be so filed but which afford a basis for liability under the 1934 Act.

The attorney may also be involved in the issuance of securities under circumstances where problems of disclosure do not relate simply to documients such as a proxy statement or prospectus. A sale of securities in colmection with a private placement or the acquisition of a closely held company, where no proxy statement is utilized, may

SEc. L. Rep. I 93,959, at 93,918; cf. Chris-Craft Indus., Inc. v. Bangor Punta Corp., No. 72-1064 (2d Cir., Mar. 16, 1973), '72-'73 CCH Fed. SEc. L. ReP. đ 93,816, at 93,510. This is the view which has been adopted in the proposed Federal Securities Code. FED. SEC. CODE, supra note 37, \& 1418. Where a defendant has been found liable as an aider and abettor (or where the complaint has been found to properly allege such liability), the facts of the cases have generally shown (or the complaint has alleged), that the defendant was indeed a conscious participant in a violation of law or engaged in "fraudulent" conduct. See Petit v. American Stock Exchange, 217 F. Supp. 21, 28 (S.D.N.Y. 1963); Brennan v. Midwestern United Life Ins. Co., 417 F.2d 147, 150-51 (7th Cir. 1969), cert. denied, 397 U.S. 989 (1970); Buttrey v. Merrill Lynch, Pierce, Feuner \& Smith, Inc., 410 F.2d 135, 144 (7th Cir. 1969), cert. denied, 396 U.S. 838 (1969).

65. SEC v. First Sec. Co. of Chicago, 463 F.2d 981, 987 (7th Cir. 1972); see also Black \& Co. v. Nova-Tech, Inc., 333 F. Supp. 468, 472 (D. Ore. 1971). 
nevertheless involve the attorney in preparation of representations for use in an agreennent which serves as the disclosure document. Furthermore, he may become aware of oral representations concerning the issuer of the securities which are not embodied in any document.

When dealing in the area of factual dissemination, unless his responsibilities are clearly defined, the attorney's role, as perceived by both the issuer and the ultimate recipient of the securities, may be more ambiguous than when he is deliverimg an explicit opinion imcluded in a disclosure instrument. He may personally verify the accuracy of certain portions of the document, such as the description of the issuer's authorized securities or stock option plans, the terms of a merger transaction, or other material contracts, where his professional skills suggest that he undertake the verification. On the other hand, in preparing the disclosure docunnent he may simply be relying on information furnished by others, such as remuneration paid to officers, the size and location of an issuer's physieal facilities, the volume of business or profitability of a particular division or product, the discovery of an important new mineral deposit, or the absence of undisclosed contingent liabilities. In these latter cases, the attorney possesses no special skills by reason of his professional training which necessitate that he personally undertake to verify the accuracy of the facts, and to require him to do so as a matter of public policy might place an unwarranted economic burden on the issuer.

By assisting in the preparation of factual docuinents to be used in transactions involving the issuance of securities or to be disseminated to the investing public, the attorney traditionally has not undertaken to ensure the accuracy of all of the infornation which appears therein. In analyzing what duties the attorney should be viewed as having undertaken with respect to such documents or with respect to oral representations of fact which are made by an issuer in connection with the sale of its securities, a useful distinction can be drawn between those instances in which the attorney voluntarily assumes a duty of imvestigation and those instances, if any, in which as a matter of public policy a duty of inquiry should be imposed. Even when the attorney has such a duty imposed upon him, a tension will exist between any obligation he may have to diselose materially misleading statements or omissions and his responsibilities to his client with respect to information which may be damaging to his chient. In addressing this latter problem we will return to Professor Isaacs' admonition that an attorney is not an ordinary employee of his client, but is also answerable to the court and to society-a view obviously shared by the SEC, as reflected in its complaint in National Student Marketing. ${ }^{66}$

66. The SEC's view as to attorneys' responsibility to assist in the enforcement 


\section{A. Affirmative Duty of Inquiry \\ Voluntarily Assumed}

When assisting in the preparation of a document intended for public dissemination, an attorney may, and indeed often does, voluntarily undertake to test the accuracy and adequacy of at least certain of the disclosures made therein. In such a case, the attorney assumes some affirmative duty of inquiry-at least to the client for whom the attorney undertook the inquiry. However, the attorney will not usually verify the accuracy of all facts in the document, and, accordingly, should take care to avoid leaving an impression with the board of directors or management of the client that he is assuming full responsibility to see that "everything is all right." A director or underwriter may not be permitted to plead by way of defense that le relied upon his attorney to verify the accuracy of a registration or proxy stateinent. ${ }^{77}$ However, if his attorney creates the impression that he is undertaking such verification and fails to do so, then the director or underwriter may well have some basis for claim against his counsel irrespective of whether nnembers of the public who relied upon the document do.

The attorney can profit from the experience of his accounting brethren and be precise in delineating for his client both the areas of inquiry for which lie assumes responsibility and what types of inquiries he is in fact inaking. When delivering comfort letters, accounting firms have becoine reluctant to make sweeping statements about the accuracy of registration or proxy statements. Instead, properly drafted comfort letters lave tended to focus on specific areas of the statement with respect to whicll comfort is sought.

of the securities laws was recently set forth in Emanuel Fields, Securities Act Release No. 5404 (June 18, 1973), CCH FED. SEc. L. ReP. II 79,407. In a proceeding to permanently disqualify an attorney from practice before the Commission, the Commission stated:

Members of this Commission have pointed out time and time again that the task of enforcing the securities laws rests in overwhelming measure on the bar's shoulders. These were statements of what all who are versed in the practicalities of securities law know to be a truism, i.e., that this Commission with its sinall staff, limited resources, and onerous tasks is peculiarly dependent on the probity and the diligence of the professionals who practice before it. Very little of a securities lawyer's work is adversary in character. He doesn't work in courtrooms where the pressure of vigilant adversaries and alert judges checks him. He works in his office where le prepares prospectuses, proxy statements, opinions of counsel, and other documents that we, our staff, the financial community, and the investing public must take on faith. This is a field where unscrupulous lawyers can inflict irreparable harm on those who rely on the disclosure documents that they produce. Hence we are under a duty to hold our bar to appropriately rigorous standards of professional honor. Id. at 83, 175 n.20.

67. Gould v. American-Hawaïan S.S. Co., 351 F. Supp. 853 (D. Del. 1972); Escott v. BarChris Constr. Corp., 283 F. Supp. 643, 697 (S.D.N.Y. 1968). 
Attorneys should likewise avoid assuming the responsibility for delivering broad forn "opinions" or letters as to compliance with the requirements of the securities laws of registration statements, proxy statements, or of the transactions of which they are a part, and should make it clear that they are not assuming responsibility for accuracy of factual matters contained in the document except as expressly indicated. $^{88}$ Furthermore, where an attorney is called upon to express an "opinion" that he is not aware of any material misstatements or omissions in a document, he should consider making clear the mquiries he has in fact made and the extent of his participation in the preparation of the document to avoid giving the impression by delivery of such an "opinion" that he has undertaken a greater scope of mquiry or participation than he in fact did. ${ }^{68}$ Similar care should also be exercised in responding to the usual independent auditor's request for information on contingent liabilities or commitments of the client, so as not to give the impression that the attorney has undertaken to make mquiry as to the existence of sucl liabilities where he has not in fact done so. It would appear to be good practice in the usual case for the attorney to confine his response to those matters whieh he is currently handling for the client and expressly to refrain from comment$\mathrm{mg}$ on the existence or absence of contingent liabilities. ${ }^{70}$

There will, of course, be many occasions when an attorney will assist in the preparation of a document for public dissemmation (such as an annual report or Form 10-K) when no formal opimion or comfort letter is expected of him. Here again, the attorney should indicate to the client what he is and what he is not undertaking to verify so that responsibilities can be clearly assigned among management, the independent auditors, and counsel for the accuracy of portions of the document.

In the area of voluntary assumption of the duty to inquire, the attorney may be able to negate any potential liability based on a thirdparty beneficiary theory if he does not hold himself out to the investing

68. Attorneys are beginning to focus more carefully on this problem. See Fuld, Legal Opinions in Business Transactions-An Attempt to Bring Some Order Out of Some Chaos, 28 Bus. LAw. 915 (1973); Cheek, Counsel Named in a Prospectus, 6 The Review of Securities Regulation 939 (No. 7, Apr. 5, 1973).

69. Counsel in the National Student Marketing case were called upon to deliver opinions as a condition to consummation of a merger that to their knowledge the parties to the merger had incurred no violation of federal or state statute or regulation. Complaint, SEC v. National Student Marketing Corp., No. 225-72 (D.D.C., filed Feb. 3, 1972) ( '71-'72 CCH FED. SEC. L. REP. If 93,360, at 91, 913-16 Tी 48(d)-(e).

70. See Deer, Lawyers Responses to Auditors' Requests for Information, 28 Bus. LAw. 947 (1973). When the attorney is personally aware of a contingent liability, consideration must be given to the factors discussed belory under Affirmative Duty of Disclosure. 
public as having assumed such a responsibility. Any comfort letter delivered by him should limit the right to rely thereon to his immediate client or the auditor to whom it is delivered and provide that it may not be referred to or quoted in any report prepared by the auditor or in the financial statements of the client without the attorney's prior written consent. Such a precaution enabled the accountants in the BarChris case to avoid having their comfort letter utilized as a basis for liability to the complaining plaintiffs. ${ }^{71}$

When the attorney has voluntarily undertaken a duty of verification, it is reasonable to hold him to a standard of reasonable care and skill in carrying out his responsibilities. If he is negligent in performing his duties, the client for whom he undertook the task should be entitled to hold him responsible in the same manner that he might be held liable for delivering an explicit opinion which proved false due to his negligence. There is, however, one very important distinction which must be drawn between the types of explicit legal opimions discussed above, and those opimions which the attorney is frequently called upon to render on which facts must be disclosed as material and what type of disclosure must be made. Although some seemingly objective standards have been suggested as to what is material, ${ }^{72}$ reason-

71. Escott v. BarChris Constr. Corp., 283 F. Supp. 643, 698 (S.D.N.Y. 1968). This technique could not, of course, be used to insulate the attorney from liability for explicit legal opinions required to be filed under Form S-1 or for opinions appearing in a prospectus or proxy statement. Quaere if an attorney should be able to negate potential liability where the delivery of an opinion is a condition to closing a transaction and public investors who receive the proxy material or prospectus are aware of the existence of the condition.

72. SEC Regulation \& 405, promulgated under the 1933 Act, 17 C.F.R. \& 230.405 (1972), defines "material" as follows:

The term "material," when used to qualify a requirement for the furnishing of information as to any subject, limits the information required to those matters as to which an average prudent investor ought reasonably to be informed before purchasing the security registered.

SEC Regulation 12b-2, promulgated under the 1934 Act, 17 C.F.R. $\$ 240.12 b-2$ (1972), similarly defines "material" but extends the definition to cover sale as well as purchase of securities. Fed. SEC. CoDE, supra note 37, section 256(a) defmes a fact as material if "a reasonable person would attach importance to it under the circumstances in determining his course of action." In Escott v. BarChris Constr. Corp., 283 F. Supp. 643, 681 (S.D.N.Y. 1968), the court quoted with approval the definition of materiality given in In re Charles A. Howard, 1 SEC 6, 8 (1934): "a fact which if it had been correctly stated or disclosed would have deterred or tended to deter the average prudent investor from purchasing the securities in question." List v. Fashion Park, Inc., 340 F.2d 457, 462 (2d Cir. 1965), determined the basic test of materiality to be whether "a reasonable man would attach importance [to the fact misrepresented] in determining his choice of action in the transaction in question"; [einphasis added] and the same court in General Time Corp. v. Talley Indus., Inc., 403 F.2d 159, 162 (2d Cir. 1968), cert. denied, 393 U.S. 1026 (1969), stated the test as "whether, taking a properly realistic view, there is a substantial likelihood that the misstatement or omission may have led a stockholder to grant a proxy to the solicitor or to withhold one from the other side, whereas in the absence of this he would have taken a contrary course" [emphasis 
able men may still differ on whether a particular fact is material ${ }^{78}$ or even on whether the manner in which it is stated in the disclosure document renders it materially misleading. ${ }^{74}$ Under such circumstances, the attorney should not be held hable for error in determining which facts should be included and which omitted, unless the misstatement or omission is so obvious that clearly no reasonable man could have thought it proper. Such a result would be consistent with the concern expressed in Lucas v. Hamm ${ }^{75}$ that unreasonable burdens not be imposed on the legal profession, and with those cases which hold that attorneys will not be held hable for honest errors of judgment or mistakes of law as to which reasonable opimions may differ. ${ }^{70}$

A recent California Supreme Court case provides some guidance in determining what classes of plaintiffs should be entitled to assert hability in the event an attorney fails to fulfill adequately a voluntarily assumed duty of verification. In United States Liability Insurance Co. v. Haidinger-Hayes, Inc. ${ }^{77}$ the court held, inter alia, that the president of an insurance broker is not hable to the insurance carrier for negligently computing the premiums due froin a chent. The carrier has a cause of action for damages against the broker, but the president, as an agent, is responsible only to his principal, the broker. The court rehed upon those provisions of the Restatement (Second) of Agency limiting

added]. The Umited States Supreme Court defined a misstatement or omission as material if "the defect was of such a character that it might have been considered important by a reasonable shareholder who was in the process of deciding how to vote." Mills v. Electric Auto-lite Co., 396 U.S. 375, 384 (1970) (emphasis added). In Gerstle v. Gamble-Skogmo, Inc., Nos. 72-2259 \& 72-2345 (2d Cir., May 9, 1973), CCH FED. SEC. L. REP. $\pi 93,983$, at 93,943, the second circuit examined these varying definitions, limited the importance of the Mills "might have been" standard by examining the posture of the case on appeal, and concluded that the Supreme Court had set too low a threshold. The court reasoned that since negligence alone suffices to invoke liability, a standard "tending toward probability rather than toward mere possibility" is more appropriate. Accordingly, the court adhered to its own prior formulations in the List and General Time cases.

73. Compare, for example, what errors were and were not found to be material in Escott v. BarChris Constr. Corp., 283 F. Supp. 643, 679-82 (S.D.N.Y. 1968). The court concluded that the understatement of sales by $6.6 \%$, earnings per share by $13 \%$, and contingent liabilities by $7 \%$ in a speculative growth-oriented company with large known contingent liabilities was not material; but that the overstatement of current assets and understatement of current liabilities, resulting in a ratio of current assets to current liabilities of 1.9 to 1 instead of 1.6 to 1 , was material. Obviously such distinctions may involve close matters of judgment.

74. See, e.g., Gould v. American-Hawaiian S.S. Co., 331 F. Supp. 981, 994-95 (D. Del. 1971).

75. 56 Cal. 2d 583, 364 P.2d 685, 15 Cal. Rptr. 821 (1961), cert. denied, 386 U.S. 987 (1962).

76. See Wade, The Attorney's Liability for Negligence, 12 VAND. L. REv. 763 (1959); Note, Attorney Malpractice, 63 Corum. L. REv. 1292, 1299 (1963).

77. United States Liab. Ins. Co. v. Haidinger-Hayes, Inc., 1 Cal. 3d 586, 594-95, 463 P.2d 770, 772, 83 Cal. Rptr. 418, $422-23$ (1970). 
the liability of agents to third persons to cases which involve physical injury and denying liability in cases which involve only pecuniary harm, whether caused by intentional or negligent conduct. ${ }^{78}$ The decision probably reflects the continuing concern of the courts about extending the class of plaintiffs to whoin a negligent defendant may be responsible. This concern and the balancing of considerations which underlie it compel a similar result im situations involving a negligent attorney: he should not be liable to third parties not in privity with him where he has not held himself out to them as having undertaken the task of verification. However, where the attorney has delivered an explicit opinion on the accuracy of facts reflected in a disclosure document, the same considerations discussed above in respect to explicit legal opinions should apply in determining those persons who can assert liability against him.

\section{B. Affirmative Duty of Inquiry Involuntarily Imposed}

Assuming that the attorney has made clear to the client what himited duties of inquiry he is voluntarily willing to assume in connection with preparation of a document, what additional duties of inquiry will be imposed upon lim by common law or by federal or state securities laws?

It might be argued that because of his professional training the attorney should be cliarged with verifying the accuracy of all inforination disseminated by his client to the investing public before it is released. However, neither present federal and state securities laws nor existing judicial decisions impose such a duty on the attorney; ${ }^{79}$

78. See Restatement (SeCond) of Agency $\$ \$ 352,357$ (1958). Section 357 states that "[a]n agent who intentionally or negligently fails to perform duties to his principal is not thereby liable to a person whose economic interests are thereby harned." Prior to the decision in United States Liab. Ins., other California cases not mentioned in that decision had permitted direct suit by third parties against an officer or director of a corporation for tortious conduct. See, e.g., Vujacich v. Southern Commercial Co., 21 Cal. App. 439, 443, 132 P. 80, 81 (1913); McClory v. Dodge, 117 Cal. App. 148, 154, 4 P.2d 223, 225 (1931); Components for Research, Inc. v. Isolation Prods., Inc., 241 Cal. App. 2d 726, 729-30, 50 Cal. Rptr. 829, 831 (1966).

79. When an attorney has participated actively in a transaction other than as an attorney or has become aware of facts which should put him on his guard, he may have an additional duty of inquiry. See SEC v. Frank, 388 F.2d 486 (2d Cir. 1968), in which the court, reversing an order enjoining an attorney pendente lite froin drafting writings on behalf of a client engaged in a securities offering, observed:

whether the fraud sections of the securities laws go beyond .... [the requirement that a lawyer not close his eyes to what he saw and could readily understand] and require a lawyer passing on an offering circular to run down possible infirmities in his client's story of which he has been put on notice, and if so what efforts are required of him, is a closer question on whicl it is important that the court be seized of the precise facts, including the extent as the 
and there is no evidence that the SEC believes such burden to be intended, despite its assertion that a public relations firm must inquire as to the accuracy of information concerning its client before disseminating information about the client to the pubhic ${ }^{80}$ and its coinplaint in the National Student Marketing case. ${ }^{81}$ The imposition of a broad duty of verification is not in accordance with present practice and would not only constitute a wasteful use of the attorney's professional talents, but mighit also impose economically unfeasible burdens on the client.

Section 11(a)(4) of the Securities Act of 1933 imposes the responsibilities of section 11 upon an expert ouly with respect to those disclosures in the registration statement which purport to have been prepared or certified by hin. As to such portions of the registration statement, section $11(\mathrm{~b})(3)(\mathrm{B})$ requires that the attorney undertake reasonable investigation of the basis for his statement or opinion. However, it has been lield that this obligation does not extend to other portions of the registration statement unless the attorney is also a director of the issuer or is otherwise a signatory to the document. The court in Escott v. BarChris Construction Corp.$^{82}$ rejected the contention that an attorney is to be viewed as having expertised the entire registration statement, stating:

The defendants do not agree among themselves as to whom the "experts" were or as to the parts of the registration statement which were expertised. Some defendants say that Peat, Marwick was the expert, others say that BarChris's attorneys . . . and the underwriters' attorneys .... were also the experts. On the first view, only those portions of the registration statement purporting to be made on Peat, Marwick's authority were expertised portions. On the other view, everything in the registration statement was within this category, because the two law firms were responsible for the entire document.

The first view is the correct one. To say that the entire registration statement is expertised because some lawyer prepared it would be an unreasonable construction of the statute. Neither the lawyer for the company nor the lawyer for the underwriters is an expert within the meaning of Section 11.

While an attorney may under some circumstances be an expert, as previously noted, the result in BarChris is a logical application of section 11(a)(4). Unless the attorney lolds limself out in the regis-

SEC claimed with respect to Frank, to which his role went beyond a lawyer's normal one. 388 F.2d at 489 (emphasis added).

80. SEC v. Pig 'N Whistle Corp., No. 71, Civil 545 (N.D. Ill., Feb. 14, 1972), '71-'72 CCH FED. SEC. L. REP. If 93,384.

81. SEC v. National Student Marketing Corp., No. 225-72 (D.D.C., filed Feb. 3, 1972), '71-'72 CCH FED. SEC. L. REP. If 93,360.

82. 283 F. Supp 643, 683 (S.DN.Y. 1968). 
tration statement as having prepared the same, the public should not be entitled to rely upon his having verified its entire contents.

Section 18(a) of the Securities Exchange Act of 1934 likewise imposes no express duty of inquiry on an attorney. It imposes liability on persons who file false documents under the 1934 Act or any rule or regulation promulgated thereunder, but permits the person sued to defend simply by proof that he acted in good faith and had no knowledge that a statement was false or misleading.

The question arises whether Rule $10 \mathrm{~b}-5$ or section 14(a) of the 1934 Act should be construed to impose a more extensive duty of investigation upon the attorney than is imposed by section 11 of the Securities Act of 1933. The inquiry can begin by examining the roles and responsibilities of other participants in the dissemination of corporate information. In Lanza v. Drexel \& $\mathrm{Co}_{.}{ }^{83}$ the United States Court of Appeals for the Second Circuit recently had occasion to review the obligation of an outside director under Rule $10 \mathrm{~b}-5$ to ensure that all n1aterial, adverse information is disseminated to prospective purchasers of a corporation's stock in an acquisition transaction, where the defendant director did not know that prospective purchasers were not receiving all material information. The court characterized any such obligation as a "duty to convey" and concluded that the outside director owed no such duty because he was essentially a non-participant in the transaction. The court further concluded that a' director's hability to prospective purchasers under Rule 10b-5 can only be secondary-as an aider and abettor, a conspirator, or a substantial participant in fraud perpetrated by others-and that the director in question was not liable on this theory.

Implicit in the court's decision was the conclusion that for one to be held liable as an aider and abettor, conspirator, or participant, he must be found guilty of conduct niore culpable than ordinary negligence and amounting to "willful or reckless disregard for the truth." 84 The court referred to its earlier opinion in Chris-Craft Industries, Inc. v. Piper Aircraft Corp. ${ }^{85}$ for the proposition that in determining what constitutes willful or reckless disregard for the truth, the inquiry norinally will be whether the defendants knew the niaterial facts misstated or omitted, or failed or refused, after being put on notice of a possible n1aterial failure of disclosure, to apprise themselves of the facts where they could have done so without an extraordinary effort. The court noted that the answer will depend upon the particular circumstances of

83. No. 35794 (2d Cir., Apr. 26, 1973), CCH FEd. SeC. L. REP. If 93,959.

84. Id., CCH Fed. SEC. L. REP. at 93,981 . II 93,816 .

85. No. $72-1064$ (2d Cir., Mar. 16, 1973), '72-'73 CCH Fed. SEC. L. Rep. 
each case, including the nature and duties of the corporate positions held by the defendants. ${ }^{80}$

In Chris-Craft Industries the Second Circuit held the First Boston Corporation, which was the underwriter for Bangor Punta in an exchange offer registered under the 1933 Act to shareholders of Piper Aircraft, liable to Chris-Craft, a disappointed contender for control of Piper. Liability was not predicated on First Boston's status as a statutory underwriter under the 1933 Act, but rested on its participation as aider and abetter of Bangor Punta in violating section 14(e) of the 1934 Act. $^{87}$ Liability was imposed because First Boston was found to have been reckless in failing to identify material falsity in Bangor Punta's registration statement. The court's view of the underwriter's responsibility-even in a non-1933 Act setting-is of interest here simce it suggests that a participant in the disclosure process inay be deemed to have held himself out as having undertaken certain investigations by reason of his role as commonly understood by the public. The court stated: 88

Section 14(e) provides that "[i]t shall be unlawful for any person to make any untrue statement of a material fact" or to mislead by omitting "to state any material fact". (Emphasis added). An underwriter or dealer-manager for a securities issue does not actually prepare the registration materials. Thus, in a literal sense, it does not "make" statements to potential investors. But we do not read § 14(e) so narrowly. An underwriter by participating in an offering constructively represents that statements made in the registration materials are complete and accurate. The imvesting public properly relies upon the underwriter to check the accuracy of the statements and the soundness of the offer; when the underwriter does not speak out, the investor reasonably assumes that there are no undisclosed material deficiencies. The representations in the registration statement are those of the underwriter as much as they are those of the issuer.

Self-regulation is the mainspring of the federal securities laws. No greater reliance in our self-regulatory system is placed on any single participant in the issuance of securities than upon the underwriter. He is most heavily relied upon to verify published materials

86. Lanza v. Drexel \& Co., No. 35794 (2d Cir., Apr. 26, 1973), CCH Fed. SEc.

L. REP. IT 93,959, at 93,832 n.8 (2d Cir. 1973).

87. 1934 Act $\& 14(\mathrm{e}), 15$ U.S.C. $\S 78 \mathrm{n}(\mathrm{e})(1970)$, provides:

It shall be unlawful for any person to make any untrue statement of a material fact or omit to state any material fact necessary in order to make the statements made, in the light of the circumstances under which they are made, not misleading, or to engage in any fraudulent, deceptive, or manipulative acts or practices, in connection with any tender offer or request or invitation for tenders, or any solicitation of security holdcrs in opposition to or in favor of any such offer, request, or invitation.

88. Chris-Craft Indus., Inc. v. Bangor Punta Corp., No. $72-1064$ (2d Cir., Mar. 16, 1973), '72-'73 CCH FED. SEC. L. REP. Tा 93,816, at 93,510. 
because of his expertise in appraising the securities issue and the issuer, and because of his incentive to do so. He is familiar with the process of investigating the business condition of a company and possesses extensive resources for doing so. Since he often has a financial stake in the issue, he has a special motive thoroughly to investigate the issuer's strengths and weaknesses. Prospective investors look to the underwriter-a fact well known to all concerned and epecially to the underwriter-to pass on the soundness of the security and the correctness of the registration statement and prospectus.

The Second Circuit appears to place greater emphasis upon the duty to convey of an underwriter because of public expectations than upon the duty to convey of an outside director. However, in both of the above cases a majority of the court held the defendant to no higher standard than that of reckless disregard of facts which should have put the defendant on notice. Perhaps in Lanza the court was simply blurring two separate inquiries: whether a "duty to convey" exists, and, if it does, what degree of culpability inust be shown to prove a breach of the duty. It is significant to note that the court in Lanza, sitting en banc, divided 6 to 4 on the question of standard of care. A strong dissent suggested that a lesser showing of culpability should be required to establish the hability of a director. There was no such dissent in Chris-Craft Industries. It can be inferred that at least some judges in the Second Circuit would hold certain participants in the disclosure process to a higher standard of care than other participants. ${ }^{89}$

What do the Lanza and Chris-Craft Industries opinions suggest as to the responsibilities attorneys may be deemed to have assumed in the disclosure process? On the basis of the court's approach to the responsibilities of First Boston in Chris-Craft Industries, it could be argued that other participants in the disclosure process-including attorneys-may be deemed to represent to the public that they are undertaking verification of the accuracy of disclosure documents even though they do not expressly undertake to do so.

However, a number of factors suggest that no imphed representation of verification similar to that imposed on the underwriter in Chris-Craft Industries slould be attributed to attorneys participating in the disclosure process:

(1) The statutory framework does not expressly obligate attorneys to deliver exphicit opinions as to or undertake factual verifica-

89. It also has been suggested that the appropriate standard of diligence for a particular section of the securities laws will be determined in regard to that section only and not by analogy to generalized considerations pertinent to other sections. See Gould v. American-Hawainan S.S. Co., 351 F. Supp. 853, (D. Del. 1972), in which the court concluded that a showing of ordinary negligence was sufficient under section 14(a) of the 1934 Act, even though a showing of greater culpability might be required under Rule 10b-5. 
tion of statements made in disclosure documents. Indeed, many of the reports or documents, such as annual reports or press releases, are not even treated as documents filed under the 1934 Act for purposes of section 18(a) liability. ${ }^{90}$

Compare the attorney's limited statutory obligations to those of the accountant, who is required by statute or regulation to furnish an auditor's report on the issuer's financial statements in connection with registration statements under the $1933^{91}$ and $1934^{02}$ Acts, merger proxy statements, ${ }^{03}$ filings on Form $10-\mathrm{K},{ }^{04}$ and annual reports. ${ }^{96}$ In the course of his audit, the accountant may well inquire into factual matters touching various portions of the disclosure document in addition to the financial statements. However, even in the case of the independent certified public accountant, it is not understood that either generally accepted accounting standards or other rules of due diligence $^{96}$ impose upon the accountant the responsibility for investigating and demanding disclosure im the issuer's financial statements or elsewhere of matters that inust be disclosed in portions of the prospectus with which he is not concerned. To create a general theory of implied representation for either accountants or attorneys would violate the statutory pattern established by section 11(b)(3) of the 1933 Act, which protects investors by placing an affirmative duty of imquiry on directors, other signatories to the registration statement, and underwriters with respect to nonexpertised sections of the registration stateinent. ${ }^{97}$

(2) When an attorney expresses an opinion on a point of law or describes the effect of a legal document, it is reasonable to assume that he has made the inquiry reasonably necessary to permit him to express an informed opinion. ${ }^{88}$ On the other hand, the attorney

90. See, e.g., Rule 14a-3(c), 17 C.F.R. $\$ 240.14 \mathrm{a}-3$ (c) (1972); Heit v. Weitzen, 402 F.2d 909, 914 (2d Cir. 1968).

91. 1933 Act, Schedule A, II (25)-(27), 15 U.S.C. \& 77aa (1970); Form S-1, Instructions as to Financial Statements.

92. 1934 Act $\S \S 12(b)(i)-(k), 12(g)(1), 15$ U.S.C. $\$ \S 78-1(b),(i)-(k), 78-1$ (g) (1) (1970); Form 10, Instructions as to Financial Statements.

93. Schedule 14-A, Item 15, 17 C.F.R. \& 240.14a-101 (1972).

94. Form 10-K, Instructions to Financial Statements.

95 Rule 14a-3(b)(3), 17 C.F.R. \& 240.14(a)-3(b)(3) (1972).

96. Regulation S-X provides that information specifically required to be included in the financial statements must be augmented by such further material and information as is necessary to make the required statements, in the light of circumstances under which they are made, not misleading. Reg. S-X, Rule 3.06, 17 C.F.R. $\$ 210.3-06$ (1972). See also United States v. Simon, 425 F.2d 796 (2d Cir. 1969), cert. denied, 397 U.S. 1006 (1970).

97. 1933 Act $\$ 11$ (b) (3), 15 U.S.C. $\$ 77 \mathrm{k}(1970)$.

98. Accordingly, it should not shock any member of the corporate bar to suggest that an attorney impliedly represents that he has examined the articles of incor- 
should not simply by participating in preparation of a document be deemed to represent that he will personally verify factual matters beyond his own knowledge, such as the existence and location of the chient's plants, the amomt of contract backlog, or the number of persons engaged in or amount spent for research and development. In many instances, the attorney is no more capable by reason of his professional training to verify such facts than would be an employee of the client, and to require him to do so might place an unreasonable economic burden on the client. ${ }^{99}$

(3) The business community does not expect the attorney to assume a generalized duty to verify facts, and leeretofore has proceeded on the assumption that in the securities area the attorney holds himself out as exercising his professional skills only with respect to those matters on which he expresses explicit legal opinions. For example, in private placements and acquisition agreements, the attorneys' opimions required as conditions precedent to closing normally do not purport to cover most of the representations and warranties given by the client. The transacting parties are accustomed to arranging other forms of protection.

(4) Each client's needs will differ, and the particular circumstances should dictate what factual verification the attorney needs to and will agree to undertake. This is a matter whicl 1 should be permitted to be worked out between the attorney and his client, who is, after all, primarily responsible for the total final document. Strict rules fixing the attorney's obligations beyond duties which would clearly be expected to be assumed by him, such as that of providing an accurate legal description of the securities, will hinder the client's ability to work out the best allocation of its financial and hunıan resources without any commensurate benefit to the imvesting public.

(5) The attorney-client privilege may preclude the attorney in some cases from making an affirmative disclosure of facts which come to his attention, and in such cases the attorney should not be held

poration of his client before expressing an opinion as to whether an issue of common stock has been validly issued within the limitations imposed by the client's charter. A similar duty of inquiry should likewise be implied where the attorney assumes the obligation to describe the client's authorized capital stock structure in a merger proxy statement.

99. In satisfying their own obligations of due diligence the board of directors or the managing underwriters may, of course, ask counsel to verify sensitive matters such as backlog; but then the attorney voluntarily undertakes an obligation to investigate. Some penumbral questions, as, for example, when a lease expires, might require the attorney to describe legal documents. But these are essentially factual descriptions which should fall within the same category as other types of factual information appearing in published reports. The attorney's duty to investigate should depend upon whether he voluntarily assumes the obligation to verify the information. 
liable on a theory of conscious participation, aiding and abetting, or scienter, for failure to disclose. The investing public should not expect a lawyer to reveal publicly his client's confidences, and no representation of verification which causes conflict with the attorney-client privilege should be implied.

\section{III.}

\section{AfFirmative Duty of Disclosure}

The preceding paragraphs lave considered the extent to which an attorney may voluntarily assume, or have imposed upon him, an initial affirmative duty to investigate the underlying facts relating to a document he is helping to prepare which will be disseminated to the public. Even though the attorney may not initially have a duty of inquiry imposed upon him, if in the course of his engagement he becomes aware of facts which put him on notice that a disclosure document may be inaterially misleading, he should at that point satisfy himself as to the accuracy of the document.

If, after investigation, the attorney determines that the document ornits material information, he must consider both the obligation the client owes to the public to provide full disclosure and the restrictions placed on him by the attorney-chent privilege. The factual situations the attorney may encounter can vary between two extremes. At one extreme, the attorney may be faced with a request to assist an obviously fraudulent scheme. For example, a client inay suggest that a corporation be formed to offer to the public securities in a business which is in fact non-existent, but which will be described in a prospectus as having properties and profitable operations. No one would doubt that in such a case the attorney must decline to serve the client; and he would also be obligated under the Code of Professional Responsibility to report the proposed scheme to appropriate regulatory authorities. ${ }^{100}$ Neither the attorney-client privilege ${ }^{101}$ nor the provisions of the Code of Professional Responsibility requiring the attorney to respect the confidences of his client ${ }^{102}$ afford protection to one who is seeking legal assistance in embarking on a criminally fraudulent scheine.

At the other extreme, the attorney may confront a situation in which a client has indisputably valid corporate reasons for nondisclosure of inaterial information. The SEC has indicated that if such reasons exist it will ordinarily not consider it a violation of the antifraud provi-

100. ABA Code of Professional Responsibility DR 4-101(C)(3), 7-102(B)

(1) (1969).

101. See 8 J. WigMORE, EVIDENCE $§ \S 2298-99$ (2d ed. 1961).

102. ABA CODE OF Professional ResponsibILITY DR 4-101 (1969). 
sions for the client to refrain temporarily from making public disclosure. ${ }^{103}$ But to what extent must an attorney exercise independent judgment as to the propriety of the nondisclosure, and to what extent should he be entitled to rely upon the attorney-chent privilege and respect his client's confidences? In analyzing the responsibilities of the attorney under such circumstances, it will be useful to examine the obligation of the issuer client with respect to disclosure, since in those cases where the law has not found it necessary to protect imvestors by imposing a duty of disclosure on the issuer client, the attorney himself should not have an affirmative duty of disclosure either.

The following analysis assumes that the client's management is acting not out of self-interest but rather in the interest of the corporation when determining whether or not to disclose a contingent liability. If the decision-making process is flawed by management's desire to protect itself from a disclosure of its own misdeeds or to permit insider trading in the issuer's securities, then the interests of the issuer's shareholders may dictate public disclosure of the facts so as to make possible recovery from the wrongdoers. Furthermore, this analysis assumes that management of the chent issuer has not embarked on a deliberate scheme to defraud the public, but rather is acting honestly, in a good faith effort to protect existing public shareholders. An on-going fraudulent scheme obviously would not be protected by the attorneyclient privilege, ${ }^{104}$ and the attorney might have an obligation to report it to appropriate authorities. ${ }^{105}$

The broad objective of the federal securities laws is to impose a duty of full disclosure of material facts on all issuers of securities

103. In re Investors Management Co., Inc., Securities and Exchange Act Release No. 9267, Investment Advisers Act Release No 289 (July 29, 1971), '70-'71 CCH Fed. SEC. L. REP. I 78,163, at 80,521-1 (1971).

104. 8 J. WIGMORE, EVIDENCE $\$$ 2298-99 (2d ed. 1961).

105. Where the contingent liability in question involves fraudulent or other criminal condnct demonstratimg moral turpitude on the part of the client's personnel, the public interest in preventing such conduct probably should outweigh the client issuer's interest in avoiding liability. Disclosure should be required. Cf. Heit v. Weitzen, 402 F.2d 909 (2d Cir. 1968). Determining the extent to which the attorneyclient privilege may be asserted by management in a stockholder's derivative action involves a similar balancing problem. See Garner v. Wolfinbarger, 430 F.2d 1093, 1101, 1103-04 (5th Cir. 1970), cert. denied, 401 U.S. 974 (1971). Although such a disclosure requirement ordinarily might be deemed to violate the privilege against selfincrimination to the extent it exposes past offenses, compare Russell v. United States, 306 F.2d 402 (9th Cir 1962), with Shapiro v. United States, 335 U.S. 1 (1947); United States v. Kahriger, 345 U.S. 22 (1952); and Lewis v. United States, 348 U.S. 419 (1955), the privilege is not available to corporations, 8 J. Wigmore, EvIDENCE $\$ 2259$ a (2d ed.1961), and therefore the issuer cannot assert the privilege as a reason for refusing to file the report incriminating its personnel. 
subject to federal jurisdiction so that not only persons who purchase securities directly from the issuer but also buyers and sellers of outstanding securities in the public trading markets may be in possession of material facts when making their investment decisions. In applying this coinprehensive mandatc for full disclosure, it must be recognized that while disclosure should ordinarily be prompt, accuracy may sometimes require a delay so that the facts can be fully ascertained and fairly stated. Although an issuer may be liable for premature disclosure which through negligence or worse misleads the public into believing a situation better or worse than it in fact is, ${ }^{100}$ the courts to date have not imposed liability on an issuer for good faith delay in making a disclosure until the facts could be accurately stated. ${ }^{107}$

Two illustrations of situations in whicl1 an issuer may refrain from making what would otherwise be inaterial disclosures are where a legitimate corporate opportunity might be dissipated through premature disclosure, and where the disclosure of a contingent liability would significantly increase the probability of a successful claim upon the corporation or otherwise damage legitimate corporate activities. It is important to distimguish avoiding contingent liabilities by nondisclosure from the nondisclosure of liabilities which have matured or of losses which have already occurred, and from the complete nondisclosure of a material claim which has actually been asserted against the issuer. There is, for example, no justification for failure to disclose to the public a material imventory shortage when discovered, or the fact that a claim in a material amount has been asserted against the issuer.

It must be recognized also that the interest in full and prompt disclosure of the issuer and those who loold and intend to keep its stock will not always coincide witl the interests of those shareholders who plan to sell their shares promptly, or of those shareholders and members of the public who are prospective purchasers. An issuer may sometimes have a legitimate interest in delaying announcement of facts which are beneficial to the corporation-as, for exaunple, news of an important new mineral discovery until the corporation can secure options on adjoining properties. Although delay in making the public disclosure may be detrimental to a shareholder who sells before the announceinent is made, a reasonable delay for valid business pur-

106. SEC v. Texas Gulf Sulphur Co., 401 F.2d 833, 850 n.12 (2d Cir. 1968), cert. denied, 404 U.S. 1005 (1971).

107. Financial Indus. Fund, Inc. v. McDonnell-Douglas Corp., No. 71-1387-9, (10th Cir., Feb. 20, 1973), CCH Fed. SEc. L. Rep. I 93,773; see also Mitchell v. Texas Gulf Sulphur Co., 446 F.2d 90 (10th Cir. 1971), cert. denied, 404 U.S. 1004 (1971) and 405 U.S. 918 (1971); SEC v. Texas Gulf Sulphur Co., 401 F.2d 833 (2d Cir. 1968), cert. denied, 404 U.S. 1005 (1971). 
poses is proper as an exception to the general requirement of prompt disclosure, ${ }^{108}$ and the selling shareholder has no cause of action. ${ }^{109}$ Certainly one who buys the corporation's securities before learning the good news can have no complaint.

Likewise, an issuer may sometimes have a legitimate interest in delaying prompt and full disclosure of facts which are detrimental to itself and its shareholders-as, for example, the existence of a contingent liability with respect to which the statute of limitations has not run. Premature disclosure might harm the issuer, and its ongoing shareholders could reasonably question whether management had faithfully discharged its obligation to them. Those who sell before disclosure would have no complaint, ${ }^{110}$ but those who buy might well. Purchasers of securities have a strong interest, protected by the securities laws, in having access to all material information about the issuer before they purchase. Hence, the interests of a corporation's existing shareholders at any given moment may be in conflict with each other and with the interests of the corporation's potential sharcholders. Where the issuer is contemplating the issuance of additional securities, whether by public financing, private placement, or through a corporate acquisition, the conflict can be resolved simply by refraining from issuing the securities until full public disclosure of all material facts can safely be made. ${ }^{111}$ Should the issuer not resolve the problem

108. American Stock Exchange Company Manual $\$ 409$, at 106 (Apr. 15, 1968); see also New York Stock Exchange Company Manual, $\$ A 2$ at A-19 (July 18, 1968). The SEC also has recognized that in some cases valid corporate reasons may exist for non-disclosure of material information, and in such cases an issuer might refrain froin making public disclosure without violating the anti-fraud provisions. In re Investors Management Co., Inc., Securities and Exchange Act Release No. 9267, Investment Advisers Act Release No. 289 (July 29, 1971), '70-'71 CCH FED. SEC. L. REP. II 78,163, at 80,521-1 (1971).

109. Astor v. Texas Gulf Sulphur Co., 306 F. Supp. 1333, 1338.39 (S.D.N.Y. 1969); see also SEC v. Texas Gulf Sulphur Co., 401 F.2d 833, 850 n.12 (2d Cir. 1968), cert. denied, 404 U.S 1005 (1971); Matarese v. Aero-Chatillon Corp., '71-'72 CCH FED. SEC. L. REP. If 93,322 (S.D.N.Y. 1971). However, where the delay in release of favorable news is accompanied by insider stock purchases, the offending insiders, if not the issuer, still may be liable to the selling shareholder. See SEC v. Texas Guif Sulphur Co., 446 F.2d 1301 (2d Cir. 1971), cert. denied, 404 U.S. 1005 (1971).

110. See Marino v. Coburn Corp. of America, '70-'71 CCH Fed. Sec. L. Rep. T 92,959 (E.D.N.Y. 1971).

111. It might be argued in the case of a merger transaction that the managements or controlling shareholders of the constituent corporations may waive any misstatements appearing in the proxy inaterial, at least where the merger agreement permits them to do so, and consummate the transaction, particularly where they lold sufficient shares to approve the transaction under state law. See Barnett v. Anaconda Co., 238 F. Supp. 766 (S.D.N.Y. 1965); Adair v. Schneider, 293 F. Supp. 393, 396 (S.D.N.Y. 1968). But see Swanson v. American Consumer Indus., 415 F.2d 1326 (7th Cir. 1969); Laurenzano v. Einbender, 448 F.2d 1, 5 (2d Cir. 1971). Whatever 
in this fashion, thereby inevitably injuring one group or another, the attorney should withdraw froin the engagement. Section 11(b)(1) of the Securities Act of 1933 suggests that in order to avoid liability under that section, the attorney should also advise the SEC in writing that he has withdrawn and will not be responsible for that part of the registration statement which he originally agreed to expertise. Notice to the SEC of withdrawal would be appropriate to revoke any previously filed consent authorizing use of the attorney's opinion in connection with the offering and reference to the attorney in the prospectus. Such course of action would not involve disclosures which might violate the attorney-client privilege or the requirements in the Code of Professional Responsibility as to preserving chent confidences. ${ }^{112}$

The attorney's dilemma cannot be so sintply resolved, however, when the issuer cannot just choose to withdraw or delay the filing of a registration statement, but is legally obligated to make a filing-as when an issuer must register under section 12(g) of the 1934 Act by having achieved the necessary asset size and number of shareholders, or inust file periodic reports on Forms 8-K and 10-K under section 13 of that Act. ${ }^{113}$ The issuer must then decide, with the advice of counsel, what information must be immediately disclosed and whether certain disclosures can properly be delayed. But the attorney and his client, both acting in good faith, might reach different conclusions on these matters of judgment. The attorney's obligation is first, to de-

support such a course of action may have had in the past, it no longer appears to be a feasible course of action after January 1,1973, the effective date of Rule 145, since merger transactions subject to that rule now stand on the same footing as other sales of securities under the 1933 Act. Accordingly, only the shareholders of the acquired corporation who were solicited (or perhaps who will receive the securities in the event of intervening transfer) may waive the misstatement.

112. Whether the attorney has a similar responsibility to notify the SEC of his withdrawal prior to filing of the registration statement should depend upon whether or not the client is proposing to embark on a deliberate scheme to defraud the public. If so, the Code of Professional Responsibility would seem to suggest that the attorney has a duty to notify appropriate public officials. See ABA CODE of Propessional RESPONSIBIITY, DR 4-101(C)(3), DR 7-102(B)(1) (1969). Under such circumstances, the attorney-client privilege should not preclude the attorney from making the disclosure. See 8 J. Wigmore, EVIDENCE $\$ \S 2298-99$ (2d ed. 1961).

113. An issuer with convertible securities or warrants outstanding may face a similar dilemma where it is legally obligated to issue securities in the event of conversion of the semior securities or exercise of the warrants. The exercise of publicly held warrants will require delivery of a current prospectus, which as a result of the adoption of Form S-16 will incorporate by reference the issuer's current filings under the 1934 Act where the issuer is entitled to use Form S-16. A similar problem may be presented where an issuer has agreed to keep an S-16 registration statement in effect for selling shareholders unless the undertaking to register allows the issuer to defer sales until connected filings can be made. While the conversion of convertible securities will normally not require a similar prospectus delivery by reason of $\$ 3$ (a) (9) of the 1933 Act, failure to make necessary disclosures in its 1934 Act filings may subject the issuer to liability under $\S 17(a)$ of the 1933 Act and $\S 10(b)$ of the 1934 Act. 
termine whether in his professional judgment the facts in question are material, and then, to advise his client of the general obligation of prompt, full disclosure ${ }^{114}$ and of the limited circumstances in which the client may legitimately delay the announcement of material facts. For example, he should be permitted to explain that the nondisclosure of a contingent liability is permissible only when the likelihood of a claim being asserted is remote and present disclosure might significantly increase the likelihood that the claim will be asserted, or if the claim when

114. The "continuous disclosure" concept upon which the SEC has placed great emphasis in recent years compels issuers subject to the requirements of section 13 of the 1934 Act to maintain continuous comprehensive disclosure for the benefit of all those dealing in their securities, or run the risk of having the privilege of access to the public trading markets suspended. 1934 Act, $\S \S 15(c)(5), 19(a)(2),(4) ; 15$ U.S.C. $\$ \$ 78 \mathrm{c}(5), 78 \mathrm{~s}(\mathrm{a})(2),(4)$. The issuer who chooses not to make full disclosure of a contingent hability in the interests of its existing shareholders could in theory request the suspension of trading in its securities until the disclosure can be made. However, in practice such a resolution of a conflict between the interests of existing and potential shareholders is usually not practicable-not only because the disclosure cannot be made promptly enough to avoid any extended period of trading suspension, but because the immeasurable potentially adverse effect on the price of the issuer's stock caused by the suspension and resulting harm to existing shareholders may be far greater than any harm which might ultimately be caused to the corporation even if the contention of liability were to be successfully asserted. For the same reason, the issuer will be reluctant to request extension of time to file a Form 8-K or Form 10-K, or a Form 10 under $\S 12(\mathrm{~g})$ of the 1934 Act-even assuming the SEC would be willing to grant such extension. See 1934 Act $\$ 12(\mathrm{~g})(1)$; 15 U.S.C. $\$ 78 l(\mathrm{~g})(1)$ (1970); Rule 12b-25; 17 C.F.R. \& 240.12(b)-25 (1972). The SEC has indicated it will generally look with disfavor upon any request for extension of time to effect filings under the 1934 Act, and that "only the most compelling and unexpected circuunstanccs justify the delay in the filing of a report and of the dissemination to the public of the factual information called for therein." Note to Rule 12b-25. Even if such an extension were obtained it would not resolve the problems of the shareholders and holders of convertible securities and warrants who later claim that they acquired the issuer's securities prior to the date the corporate disclosure was made in the issuer's reports. The choice as to whether or not disclosure is appropriate may not be available to the issuer to the extent that its independent certified public accountant becomes aware of the contingent hiability and requires its disclosure as a condition to certifying the issuer's financial statements which must be filed as part of Form 10-K. To the extent that the accountant is advised of the contingent hability, the attorney may not assert the attorney-client privilege with respect thereto (see Himmelfarb v. Umited States, 175 F.2d 924, 939 (9th Cir. 1949), and no accountantchent privilege exists with respect thereto (see Couch v. United States, 409 U.S. 322 (1973); but see, Weck v. District Court of Second Judicial Dist., 158 Colo. 521, 408 P.2d 987 (1965) ). A brief disclosure of a coutingent liability which is not reflected in the balance sheet must be nuade in the issuer's financial statements and where appropriate, reserves may be required to be established. See Reg. S-X, Rules 3-16(i) (3), 5.02.36, 5.04 (Schedule XII), 12.13; 17 C.F.R. § 210.3-16(i) (3) (1972), 5.02.36, 5.04 (Schedule XII), 12.13; see also Accounting Series Release No. 42, CCH Fed. Sec. L. ReP. If 72,060; 1 CCH AICPA ACcounting PrInciples fit 5513-14. The SEC has indicated that the independent accountant bears an affirmative responsibility to inquire as to the existence of contingent liabilities and to see that they are properly disclosed. See Accounting Series Release No. 133, CCH FED. SEC. L. REP. II 72,155; American Tung Grove Devs., Inc., 8 S.E.C. 51, 62 (1940). 
asserted would not have a material adverse effect on the issuer's business. He should normally advise disclosure if there are defenses to the potential claim, if a loss would be adequately covered by insurance and disclosure would not jeopardize the insurance coverage, or if the potential claimant is already aware of his rights and disclosure by the issuer is not apt to provoke a lawsuit. ${ }^{115}$ But the final decision on disclosure, assuming a good faith effort to balance the factors involved, will often be one as to which reasonable minds could differ.

In analyzing what the corporate attorney's responsibilities should be in this context, consider what interests he inust represent-who his client really is. As discussed above, there are potential conflicts among continuing shareholders, shareholders seeking to sell, and shareholders and others who are potential investors. Any decision as to disclosure or non-disclosure of inaterial information will adversely affect one group or another. Under these circumstances the attorney has no basis for favoring one group of shareholders or investors over another: he must represent the corporation as an ongoing entity. While public disclosure is the general rule, the attorney should be able to abide by the good faith decision of the corporate management that nondisclosure is necessary to protect valid business interests of the corporation. The attorney should not have to inake a disclosure of the inforination on his own or withdraw his services. He does not owe a greater obligation to purchasers who would not have purchased had they known of undisclosed bad news than he does to sellers who would not have sold had they known of undisclosed good news. ${ }^{116}$ And, of course, in most cases it will be in the best interests of the corporation to make coinplete disclosure of contingent habilities and other material information to minimize the corporation's exposure froin persons who purchased or sold their stock without important knowledge. The ultimate question should always be whether inanagenent in good faith believed that the potential harm to the corporation from disclosure would be so great as to justify delayed release of material inforination; and the attorney should be able to serve his corporate client without the neces-

115. Instruction 1 to Item 5 of Form $10-\mathrm{K}$ permits omission of disclosures of litigation if the business of the registrant ordinarily results in such litigation unless it departs from the normal kind of litigation. See Hafner v. Forest Laboratories, Inc., 345 F.2d 167 (2d Cir. 1965). See also, Phillips v. Reynolds, 297 F. Supp. 736 (E.D. $\mathrm{Pa} .1969$ ). However, see paragraph (b) (7) of Item 1 and Instruction 4 to Item 5 of Form 10-K with respect to the required disclosure of impact of compliance with requirements respecting environmental quahity on the registrant's business.

116. The decision in Garner v. Wolfinbarger, 430 F.2d 1093 (5th Cir. 1970), cert. denied, 401 U.S. 974 (1971), which allows existing shareholders access to communications between the attorney and the issuer client, subject to judicial supervision, does not change this result. See also, ABA Code of Professional Responsidility, EC-5-18 (1969), which provides that a lawyer employed by a corporation or other entity owes its allegiance to the entity and not a stockholder, director, officer, employee, representative or other person connected with the entity. 
sity of independently reviewing the correctness of management's good faith decision.

It can, of course, be contended that any time a client issuer files a Form 10-K with knowledge that the report omits a material contingent liability or potential good news it is committing a "fraud" on those members of the public who rely on the report when buying or selling the issuer's outstanding securities, and that the attorney who assists in preparation of the report is an "aider and abettor" of a known violation of law. However, so long as the attorney fully explains to his client its obligations and risks (including the possibility of requesting suspension of trading in the issuer's securities), and the issuer's management or board of directors demonstrates a good faith effort to protect the corporation's interests, he should not liave a duty to second-guess his client and advise the SEC that material information is undisclosed, nor should he be held hable in damages as an "aider and abettor" or subjected to professional discipline or regulatory proceedings even if a court later decides the client's decision was improper. ${ }^{117}$ To conclude that an attorney inust override his client's business judgment and personally reveal all undisclosed material information of which he is aware in a case where the client is legally obligated to publish a disclosure document would conflict with one of the basic social policies underlying the attorney-client privilege: that of encouraging clients to seek legal advice. ${ }^{118}$ Indeed, to burden securities lawyers with a general burden of public disclosure could be counterproductive. The corporate securities bar today, because of its skills in fact gathering and dissemination and its high standard of professional responsibility, plays a vital role in realizing the goals of the securities laws and ensuring that the flow of information to the mvesting public is as complete and accurate as possible. Were corporate managers to feel that their attorneys were no longer entitled to act in their traditional role of confidential counselor to corporate clients, they might be less inclined to communicate with their attorneys and become overly cautious about what they would reveal. The end result might then be less, rather than more disclosure of material information. Of course, it does not follow that the issuer chient will never be liable where the attorney is not obligated to report a nondisclosure. If purchasers or sellers of the corporation's securities are

117. Even in cases involving independent certified public accountants, who owe no duty of confidentiality to their clients, the conrts to date have not been willing to impose a dnty to warn the public - at least as to facts discovered which do not relate to financial statements which the accountant certified. See Wessel v. Buhler, 437 F.2d 279 (9th Cir. 1971); Fisclier v. Kletz, 266 F. Supp. 180, 195-96 (S.D.N.Y. 1967); Gold v. DCL, Inc., 72 Civ. 4193 (S.D.N.Y., June 29, 1973), CCH FED. SEC. L. REP. โ 94,036 .

118. 8 J. WiGMORE, Evidence $§ 2291$, at 552-53 (2d ed. 1961). 
in fact damaged by nondisclosure, and if a court decides that the corporation did not act prudently, the damaged parties can be compensated. But at least the question of liability is properly presented: whether the client issucr's management exercised prudent judgment based on valid business reasons in attempting to protect the issuer while leeding the full disclosure objectives of the securities laws. ${ }^{110}$ To put all this in proper perspective, we should remember that we are liere discussing cases where voluntary abstention from filing of a disclosure document is not possible. Only infrequently in such a case will an attorney need to be silent about the omission of material facts from a disclosure document. In the usual case the attorney will weigh and determine the materiality of facts, and see that disclosed facts are accurately stated. It should be the rare case in which a failure to disclose facts which are ripe for disclosure will be justified. The chent's and the lawyer's basic objective should be to make disclosures as completely and promptly as possible.

\section{IV.}

\section{Responsibilitites to Correct Previously DISSEMINATED INFORMATION}

What duty should be imposed upon the attorney to correct opinions once given, or to require factual corrections in documents he helped to prepare, when facts subsequently come to his attention which make his work inaccurate? The Restatement of Torts adopts the view that a party is under a duty to exercise reasonable care to disclose to the other party to a busmess transaction before it is consummated any subsequently acquired information which he recognizes as making untrue or misleading a previous reprcsentation which, when made, was true or beheved to be so. ${ }^{120}$ One court has utilized this section by analogy to place an obligation on independent certified public accountants to correct or withdraw an opimion previously given when subsequent facts showed the financial statements reported upon to be materially misleading. ${ }^{121}$

Before a transaction is consummated, it is reasonable to require an attorney to withdraw or correct his opimion on the basis of subsequently discovered facts. However, if a public offering has already

119. Where fraudulent conduct is involved, an intent to protect the issuer may not be sufficient, even if proven. See Heit v. Weitzen, 402 F.2d 909 (2d Cir. 1968), cert. denied, 395 U.S. 903 (1969). As to whether good faith may be a defense, see 2 BRomberg, SECURITIES LAW $\$ 8.4(567(2)$ ) (Supp. 1971).

120. Restatement of Torts $\$ 551(b)$ (1938). See also Fed. Sec. Code, supra note 37, §§ 1301(d), 1304(d).

121. Fischer v. Kletz, 266 F. Supp. 180 (S.D.N.Y. 1967). 
occurred or a merger has been consummated, the duty to correct or withdraw should depend upon the nature of the correction required, the extent to which failure to publicize the subsequently discovered facts could cause additional harm to those entitled to rely upon the disclosure document, and the availability of alternative courses of action. In view of the attorney-client relationship, where some correction is required, the best policy would be for the attorney to advise the issuer client that a correction is necessary and place on the client the responsibility to take any necessary steps, rather than to publish the correction himself. This policy is especially important when there might be reasonable difference of opinion as to whether a correction should be made, ${ }^{122}$ and is most obviously proper when the subsequently discovered facts relate to matters as to which the attorney rendered only a fact-gathering function in which lie did not identify himself to the public as the factgatherer, rather than an expert, opimon-giving function in which lie identified himself as the giver of the opinion. ${ }^{123}$

Normally, the attorney can expect a client to correct erroneous information once the matter is brouglit to its attention. If the client declines to do so, then the attorney must determine whether the chent is engaged in a conscious attempt to defraud or is acting with a bona fide intent to protect the corporation. If the former, the attorney should be obligated to report the matter to appropriate regulatory authorities; if the latter, the attorney should be bound by the attorneyclient privilege to remain silent. In evaluating the attorney's response, however, a court should heed the admonition of the district court in Lanza and take care how "agonizingly subtle" we inake the attorney's choices. ${ }^{124}$ To hold the attorney in error it should be reasonably clear that the wrong is palpable and that the balance of advantage lies im imposing an obligation to issue a public warning.

122. Cf. Gold v. DCL, Inc., 72 Civ, 4193 (S.D.N.Y., June 29, 1973) (CCH FED. SEC. L. REP. \94,036, at 94,169.

123. Existing decisions concerning accountants recognize that mere possession and nondisclosure of material facts does not create liability under Rule 10b-5 absent some relationship which generates a duty to inform, and that the relationship of a certified public accountant does not create such a duty with respect to financial statements as to which the accountant lias not issued his opinion or publicly certified. See Gold v. DCL, Inc., 72 Civ. 4193 (S.D.N.Y., June 29, 1973), CCH FED. SEC. L. ReP. If 94,036; Wessel v. Buhler, 437 F.2d 279 (9th Cir. 1971); Fischer v. Kletz, 266 F. Supp. 180, 195-96 (S.D.N.Y. 1967). In view of the policy reflected in the attorney-client privilege, the same result slould apply a fortiorari as to attorneys. But see ABA CoDE OF Professional RESPONSIBILITY DR7-102(b) (1) (1969).

124. See Lanza v. Drexel \& Co., No. 35794 (2d Cir., Apr. 26, 1973), CCH Fed. SEc. L. REP. If 93,959, at 93,333, where the second circuit quoted with approval the district court's admonition. 
V.

\section{STATE Securities LaWs}

The Uniform Securities Act, which has been adopted with certain variations in most states, does not in terms attempt to impose liability on attorneys as experts who by delivering. opinions facilitate the sale of securities. Section 410(a) of the Uniform Securities Act imposes civil hability on any person who "offers or sells" a security in violation of the registration provisions of the Act or by means of any untrue statement or any omission to state a material fact necessary in order to make the statements made not misleading. Section 410 (b) of the Act provides that every person who directly or indirectly controls a seller liable under subsection (a), every partner, officer or director of such a seller, every person occupying a similar status, every employee of such a seller who materially aids in the sale, and every broker-dealer or agent who materially aids in the sale is also liable, jointly and severally, with and to the same extent as the seller, unless the non-seller who is so liable sustains the burden of proof that he did not know, and in exercise of reasonable care could not have known, of the existence of the facts by reason of which the liability is alleged to exist.

Attorneys, accountants and other experts are not expressly included among the "non-sellers," or collateral defendants, who may be held liable for materially aiding in a sale proscribed by the Uniform Securities Act. It is, of course, possible that such collateral defendants could still be held hable under a theory of "aiding or abetting" or "participation," as under the Federal Securities Laws. ${ }^{125}$ The state of Oregon has expressly provided for this result by expanding section 410 (b) to impose liability on "every person who participates or materially aids" in an unlawful sale. ${ }^{126}$

The district court in Black \& Co. v. Nova-Tech, Inc. ${ }^{127}$ used the broader Oregon version of section $410(\mathrm{~b})$ to hold that when an attorney prepared the legal papers necessary for the issuer to complete the sale of its securities, he could be served as defendant in a suit charging him with participation in an unregistered sale of securities to Oregon residents. The court observed that even if the attorney did not know and could not have known of the issuer's failure to register its securities, he was a participant in the sale because without his assistance the sale would not have occurred. The court also held the firm of which the attorney was a partner subject to service as a participant since it authorized the issuer to include the firm's name in its annual reports, which were used in connection with the sale. In

125. Id.

126. ORE. Rev. STAT. § 59.115(3) (Supp. 1969).

127. 333 F. Supp. 468 (D. Ore. 1971). 
Adams v. American Western Securities, Inc., ${ }^{128}$ the Oregon Supreme Court recently held that an attorney is entitled to assert by way of defense to a suit under the Oregon Blue Sky Law that he had no knowledge of the violation of law in which he was charged with participating. In so doing, the court observed that the decision in Black was not binding on it, and that some of the statements in the Black opinion may be overly broad if literally applied.

The effect of the Black holding is that a simplistic "but for" test is used to bring in the attorney as a "participant," and his firm is threatened with what looks like vicarious liability sinply because its name appeared on an annual report. The problem posed by Black could have been approached very simply in terins of whether the defendant attorney or his firm had undertaken to satisfy any blue sky law requirements im connection with the issuer's proposed private placement. If so, then the law firm had assumed a duty to the complaining brokerage firm which required it to use due diligence to ascertain that all necessary blue sky requirements had been satisfied. Even if it had not nndertaken such a duty, if it became aware of the necessity of satisfying such requirements, under Adams it would have been required to see that the requirements were satisfied or withdraw from the transaction.

Section $410(b)$ of the Uniform Securities Act imposes liability upon a collateral defendant covered by that section unless he sustains the burden of proof that he did not know, and in the exercise of reasonable care could not have known, of the existence of the facts by reason of which his liability is asserted. ${ }^{129}$ The comparable provision of the Califorma Corporate Securities Law was intentionally drawn more narrowly than section 410 (b) to require actual knowledge of the false or inisleading nature of the statement in question or knowlege of facts which would give the collateral defendant reasonable grounds to know that the statement was false or misleading, whether or not he in fact beheved it to be so. ${ }^{130}$

Accordingly, at least under the Califormia Corporate Securities Law the standard of diligence imposed is similar to that adopted under Rule $10 \mathrm{~b}-5$ by the majority of the second circuit in Lanza. Whether a

128. Adams v. American-Western Securities, Inc., 3 CCH BLUE SkY L. ReP. II 71,022 (Ore., May 17, 1973).

129. Although section $410(\mathrm{~b})$ has been viewed as imposing a duty of inquiry upon the collateral defendants covered thereby, MARSH \& Volx, PRACTICE UNDER THE Californta Corporate Securrties Law of 1968451 (1969), the second circuit recently indicated by dictum that no affirmative duty of investigation had been intended. Lanza v. Drexel \& Co., No. 35794 (2d Cir., Apr. 26, 1973), CCH Fed. SEc. L. Rep. If 93,959 , at 93,834 n.105.

130. Cal. CoRp. COde $\S 25,504$ (West Supp. 1972); Marsh \& Volk, supra note 129 , at 451. 
heavier affirmative duty of inquiry will ultimately be imposed under the Uniform Securities Act remains to be seen. However, if attorneys are to be held liable on a theory of "aiding and abetting" or "participation," there is a growing body of authority suggesting that the facts must slow conscious participation in a known breach of duty or knowledge of facts sufficient to put the attorney on notice that he must make further inquiry. ${ }^{131}$ Such a construction of the Uniform Securities Act would result in a standard of care substantially identical to that adopted under California statute.

The attorney may also assume a duty to determine whether registration is required at all under state securities laws. ${ }^{132}$ This responsibility is similar to that of delivering an opinion on whether a sale of securities is exempt from registration under the 1933 Act. Consequently, it would be reasonable to apply the same standard of diligence as is applied to transactions under the 1933 Act which are not subject to section 11 thereof. The attorney should be responsible for negligence only to those persons for whose direct benefit the opinion is prepared, althougl he may be hable to a broader class of plaintiffs if a higher degree of culpability is proved. However, the question of state jurisdiction over registration of securities-particularly in the case of an interstate sale of securities-is not always a clear one. ${ }^{133}$ As when offermg an opinion on the existence of a valid private placement under section 4(2) of the 1933 Act, an attorney sliould not be held negligent unless the requirement of registration is clearly beyond dispute. ${ }^{134}$

When a state -securities law does not make any provision for civil liability with respect to persons selling securities who fail to register thereunder, ${ }^{135}$ an attorney should not be held liable for participating in or aiding and abetting a sale made without registration. However, where the attorney delivers an explicit opinion or otherwise undertakes to render professional services in connection with such a sale he arguably

131. Restatement of TorTs $\$ 876$ (b) (1938); Fed. Sec. Code, supra note 37, $\$$ 1418; Ruder, Multiple Defendants in Securities Fraud Cases, 120:2 U. PA. L. REv. 597, 620-38 (1972); Folk, supra note 8, at 202; Lanza v. Drexel \& Co., No. 35794 (2d Cir., Apr. 26, 1973), CCH FED. SEc. L. REP. $\{(93,959$.

132. Note that in Black \& Co. v. Nova-Tech, Inc. the question was one of failure to qualify under the Oregon Blue Sky Law rather than of material misstatements or omissions of fact.

133. See, e.g., Doherty v. Bartlett, 81 F.2d 920, 928 (1st Cir. 1936); Lane v. Griswold, 273 N.C. 1, 159 S.E.2d 138 (1968); Robinson v. Cupples Container Co., 316 F. Supp. 1362 (N.D. Cal. 1970). The courts do not always agree as to the jurisdictional applicability of the Uniform Securities Law. See Kreis v. Mates, 473 F.2d 1308 (8th Cir. 1973), rev'g 335 F. Supp. 1299 (E.D. Mo. 1971).

134. See Lucas v. Hamm, 56 Cal. 2d 583, 364 P.2d 685, 15 Cal. Rptr. 821 (1961), cert. denied, 386 U.S. 987 (1962); Wade, The Attorney's Liability for Negligence, 12 VAND. L. REv. 755, 763 (1959); Note, Attorney Malpractice, 63 ColOM. L. REv. 1292, 1299 (1963).

135. See Sajor v. Ampol, Inc., 275 N.Y. 125, 130-31, 9 N.E.2d 803, 806 (1937). 
Inay still incur liability under the federal securities laws or at common law. Even where state statutes do not provide a basis for liability, the common law inay supply the legal doctrines necessary to impose responsibilities similar to those found under federal law. In view of the policy considerations discussed earlier, this result should reflect a proper balancing of the numerous interests involved. ${ }^{136}$

136. In a number of recent federal securities law cases the courts have begun to utilize the Restatement of Torts as a guide in determining responsibilities under the federal securities laws. At least one author has cautioned against the uncritical application of the Restatement of Torts in defining liabilities under the securities laws, particularly since the drafters did not consider the effect of their work upon the securities laws. (See Ruder, Multiple Defendants in Securities Fraud Cases, 120 U. PA. L. Rev. 597, 616 n.74 (1972). Publication of those portions of the proposed Federal Securities Code dealing with civil hability may prompt the courts in the future to look to that document rather than the Restatement of Torts for guidance in this area. In any event, the Restatement of Torts as it is proposed to be revised should not produce responsibilities far different from those discussed in this Article. RestateMENT OF TORTS $\$ 552$ (1938), which deals with responsibilities for information negligently supplied for the guidance of others, provides:

552. Information Neghigently Supplied for the Guidance of Others.

One who in the course of his business or profession supplies information for the guidance of others in their business transactions is subject to liability for harm caused to them by their reliance upon the information if

(a) he fails to exercise that care and competence in obtaining and communicating the information which its recipient is justified in expecting, and

(b) the harm is suffered

(i) by the person or one of the class of persons for whose guidance the information was supplied, and

(ii) because of his justifiable reliance upon it in a transaction in which it was imtended to influence his conduct or in a transaction substantially identical therewith.

REsTATEMENT (SECOND) OF TORTS $\$ 552$ (Tent. Draft No. 12, 1966), provides

(1) One who, in the course of his business, profession or employment, or in a transaction in which he has a pecuniary interest, supplies false information for the guidance of others in their business transactions, is subject to liability for pecumiary loss caused to them by their justifiable reliance upon the information, if he fails to exercise reasonable care or competence in obtaining or communicating the information.

(2) Except as stated in subsection (3), the liability stated in subsection (1) is liunited to loss suffered

(a) by the person or one of the persons for whose benefit and guidance he intends to supply the information, or knows that the recipient intends to supply it; and

(b) through rehance upon it in a transaction which he intends the information to influence, or knows that the recipient so intends, or in a substantially similar transaction.

(3) The liability of one who is under a public duty to give the information extends to loss suffered by any of the class of persous for whose benefit the duty is created, in any of the transactions in which it is intended to protect them.

The comments to section 552 as it is proposed to be revised make clear that where there is no intent to deceive, but only good faith coupled with negligence, the fault of the maker of the misrepresentation is sufficiently less to justify a narrower responsibility for its consequences. See RESTATEMENT (SECOND) OF TORTS $\$ 552 \mathrm{com}$ ments $a, h, i$ and $j$ (Tent. Draft No. 12, 1966). Subsection (3) to proposed section 552 imposes a liability upon one who is under a public duty to give information to any of the 


\section{CoNCLUSTON}

As a result of the decision in Black and Co. v. Nova-Tech, Inc. and the action of the SEC in filing the National Student Marketing complaint, the clarification of the responsibilities of attorneys under federal and state securities laws will become an imcreasing focus of concern for the Bar and the courts in the years immediately ahead. ${ }^{137}$ Clarification will be undertaken in the face of three significant trends: (1) the increasing integration of disclosure responsibilities under the 1933 and 1934 Acts prompted not only by enforcement of the SEC's continuous disclosure policy, but also by the adoption of Rule 145 and Form S-16; (2) the restatement in the proposed Federal Securities Code of the responsibilities of those who participate in the disclosure process without regard to distinctions presently drawn between the 1933 and 1934 Acts; and (3) the continuing effort of the courts to formulate some rational and consistent standards of care for those who participate in the disclosure process of the 1933 and 1934 Acts. ${ }^{138}$

class of persons for whose benefit the duty is created. However, comment $(k)$ to this proposed subsection (3) sets forth as illustrations only cases where a limited class of persons may be able to assert liability. In any event, under this analysis the supplier of information contemplated by section 552 would appear to be the principal defendant who is in fact supplying the information, and the attorney, as a collateral defendant, would be held liable to the extent he falls within the scope of section $876(d)$ of the Restatement of Torts, as one who knows that the principal defendant's conduct constitutes a breach of duty and gives substantial assistance or encouragement to the other so to conduct himself.

137. Concern has already begun to focus on the necessity of clarifying the responsibilities an attorney is described as assuming in prospectuses and in letters to accountants. See 6 Review of Securities Regulation (No. 7, April 5, 1973); Deer, Lawyers' Responses to Auditors' Requests for Information, 28 Bus. Law. 947 (1973). Fuld, Legal Opinions in Business Transactions, 28 Bus. LAw. 915 (1973). The corporate bar should perhaps consider taking steps to adopt the following as additional rules of professional conduct: (1) The name of an attorney should appear in a document intended to inform the public as to the business or fimancial condition of an issuer which is filed or disseminated to the public only if required by statute or regulation, or by underwriters of the securities described therein, or if required by the certified public accountants auditing financial statements accompanying the document to permit them to express their opinion. Such a requirement would normally precludo the name of an attorney from being shown as counsel for an issuer on its annual report. (2) Where the name of an attorney does appear on such a document, it should clearly describe the extent to which the attorney has assumed responsibility for material appearing in the document. The adoption of such rules should avoid any possible argument that an attorney may be misleading the public as to the extent to which he las participated in the preparation of or assumed responsibility for a public document in which his name appears, and thus lay to rest the spectre of vicarious liability raised by Black \& Co. v. Nova-Tech, Inc., 333 F. Supp. 468 (D. Ore. 1971).

138. See, in this regard, Lanza v. Drexel \& Co., No. 35794 (2d Cir., Apr. 26, 1973), CCH Fed. Szc. L. ReP. I 93,959; Chris-Craft Indus., Inc. v. Bangor-Punta Corp., No. 72-1064 (2d Cir., March 16, 1973), CCH Fed. Sec. L. REP. T 93,816; Gerstle v. Gamble-Skogmo, Inc., Nos. 72-2259 \& 72-2345 (2d Cir., May 9, 1973), 
The scope of the attorney's duties to investigate and disclose must reflect a reasonable balance between the interest of the imvesting public in full disclosure of material information and the necessity of protecting the attorney-client privilege to promote unrestricted communication between the attorney and his corporate client. As this Article has indicated, the attorney will usually have the same objective as the independent certified public accountant in insuring that full disclosure is inade, and in this sense Professor Isaac's observation is indeed valid-for in carrying out his professional responsibilities to his client, the attorney will also promote the public's interest in freely available corporate information. Only in rare, exceptional cases will the good-faith issuer, properly advised, not disclose information about the existence or scope of material contingent liabilities or corporate opportunities to protect the corporation, and only then might the attorney's obligation to his client conflict with his more general obligation to society.

CCH Fed. SEC. L. Rep. $\{$ 93,983; Gould v. American-Hawaiian S.S. Co., 351 F. Supp. 853 (D. Del. 1972). 


\title{
California Law Review
}

\begin{tabular}{lll}
\hline \hline VoL. 61 & SEPTEMBer 1973 & No. 5 \\
\hline \hline
\end{tabular}

\section{BOARD OF EDITORS}

\author{
Editor in Chief \\ ChrISTOPHeR H. Schroeder
}

Executive Editor

E. ELIZABETH SUMmens
Managing Editor

RANDALL IRA BARKaN

\section{Articles \& Book Reviews \\ Howard alan Latin \\ Patricia D. Douglass \\ JULIE E. MCDONALD \\ George RUthergleN \\ ULRICH WAGNER}

\section{Notes \& Comments}

Robert M. JENKINS, III

Wirliam A. Cardwell Richaro Delgado

ROBERT A. GOODIN

JAMES E. HARTLEY

SUSAN SAWYER

Robert E. WILLETT

Thomas S. Williamson, Jr.

\author{
Managing \\ Mary M. Loghlbo \\ Research \\ Eliot S. JUBbLIRER \\ Thom GreEnfield SeatoN \\ PATRICE W. WALSH
}

\section{Associate Editors}

CharLes Frederick AdaMs

JAMES A. ASEEW

Paul Clark

GARX JAY COHEN

PHIIIP R. DIAMOND

JOHN A. GLOGER

Douglas L. HAMMER

MARTIN WAYNE JOHNSON
ROBERT L. LAWRENCE

PETER LOMHOFF

Charles H. Matthews, Jr.

RANDALL R. MCCATHREN

ALAN MTTTMAN

LISE A. PEARLMAN

LARRY PeITZMaN
Administrative Assistant
Patricia G. SMTth

Joseph P. Powers

JAMES D. RICHMAN

HenRX Shields, Jr.

ScotT SonNe

Nancy E. Sullivan

ANNE MCLEOD TREBILCOCK

Catalina Valencta

DAVID L. WAONER 